\title{
Un esperpéntico asuntillo de Estado: la Casa de los Tomé en el Setecientos burgalés
}

\author{
Francisco José Sanz de la Higuera \\ IES Torreblanca (Sevilla) ${ }^{1}$
}

CES.XVIII, núm. 21 (2011), págs. 287-318.

1 A Nicolás Pérez Rosado, excelente compañero de trabajo, brillante conversador, magnífico escuchador, entrañable amigo, un ser humano como pocos, siempre dispuesto a la solidaridad. 
Resumen: El intento de desahucio de su vivienda, propiedad del Cabildo catedralicio, generó un turbio proceso en el cual don Pedro Tomé, primero, y su viuda, doña Josefa Carrera, después, convirtieron un mero asunto urbanístico en un complicado y espinoso asunto de Estado, preñado, sin duda, de connotaciones políticas. La pretensión del Cabildo — rehabilitar el edificio 123 de la plaza del Sarmental_ provocó enfrentamientos a múltiples niveles entre el Estado borbónico y el Cabildo catedralicio de Burgos. Las «covachuelas»y las redes de influencia activaron sus exigencias y requiebros.

Palabras clave: Desahucio. Vivienda. Catedral. Estado borbónico. Redes de influencia. Covachuelas. 
La pretensión de la Mesa Capitular de la Catedral de Burgos de hacer abandonar a don Pedro Tomé González, en primera instancia, y posteriormente a su viuda, doña Josefa Carrera, el usufructo de sendos edificios de su propiedad en la plazuela del Sarmental va a generar una problemática de insospechado calado en la que se verán implicados los responsables borbónicos, la catedral metropolitana y el Concejo burgalés, la Real Chancillería de Valladolid y algunos de sus vecinos, laicos y eclesiásticos, más prominentes. Las exigencias urbanísticas de la Administración borbónica y, en concreto, la rehabilitación de un edificio propiedad del Cabildo catedralicio enturbiaron de una manera agria sus agitadas relaciones.

Las estrategias del Cabildo ${ }^{2}$ apuntaron hacia un enfrentamiento, tácito o soterrado, con las autoridades borbónicas. Se utilizó la problemática de la vivienda de uno de sus «clientes», de uno de sus lugartenientes más afamados, Pedro Tomé, para zaherir la autoridad de la Corte y las responsabilidades de gobierno y de la recaudación fiscal. Dichos inmuebles ${ }^{3}$ fueron ocupados por el hogar conformado por don Pedro y doña Josefa desde $1723^{4}$. El período de alquiler, 1723-1782, es uno de los más dilatados en Burgos durante el Setecientos, prueba inequívoca de su vocación por ocupar un lugar de élite en la trama urbana ${ }^{5}$.

2 Sobre Cabildos catedralicios, véanse, entre otras muchas, Maximiliano BARrio Gozalo, Estudio socio-económico de la Iglesia de Segovia en el siglo XVIII, Segovia, Universidad de Valladolid, 1992. Antonio Cabeza Rodríguez, La vida de una catedral del Antiguo Régimen, Palencia, Junta de Castilla y León, 1997. Antonio Canovas Bоті́a, Auge y decadencia de una institución eclesial: el Cabildo Catedral de Murcia en el siglo XVIII. Iglesia y sociedad, Murcia, Universidad de Murcia, 1994. Luis Carlos García Figuerola, La economía del Cabildo salmantino en el siglo XVIII, Salamanca, Universidad de Salamanca, 1989. Pedro QuinTANA Andé́s, Finis gloriae mundi. Ideología y sociedad en Canarias. Los prebendados del Cabildo Catedral durante el Antiguo Régimen (1483-1820), Gobierno de Canarias, 2004 y A Dios rogando y con el mazo dando. Fe, poder y jerarquía en la iglesia canaria: el Cabildo Catedral de Canarias entre 1483-1820, Las Palmas de Gran Canaria, Cabildo de Gran Canaria, 2003, y Rafael Vázquez Lesmes, Córdoba y su Cabildo catedralicio en la modernidad, Córdoba, Monte de Piedad y Caja de Ahorros de Córdoba, 1987.

3 En concreto, los titulados con los números 123 y 123 bis en los Libros de Redondo de la catedral. Archivo Capitular de la Catedral de Burgos (en lo sucesivo ACCB). Libros de Redondo (1700-1799).

4 ACCB. Ibidem (1721-1725). La casa se arrendó por 175 reales/año. En 1722 «se demolió la mayor parte y lo que estaba habitable se arrendó a Dn Pedro Thomé en 175 reales». En 1724 se fabricó de nuevo y se le alquiló al dicho Tomé. En 1725 ya estaban hábiles los dos edificios. El 123 se alquiló por 9 años en 600 reales y 15 gallinas de a 3 reales/gallina y el 123 bis en 300 reales y 5 gallinas.

5 Sobre el hogar de Pedro Tomé y Josefa Carrera, véanse, a título de ejemplo, Francisco Sanz DE LA HIGUERA, «Las restauraciones del Consulado de Burgos en el siglo XVIII», Historia, Instituciones, Documentos, 29 


\section{Fuentes documentales}

La reconstrucción de los acontecimientos que traemos a colación ha sido posible merced a la utilización de varias fuentes documentales. El «yacimiento» esencial se encuentra redactado en las actas capitulares de la catedral de Burgos $^{6}$. Los cabildos catedralicios generaron múltiples anotaciones sobre la controversia surgida entre don Pedro Tomé y doña Josefa Carrera y la Mesa Capitular, con el telón de fondo de los edificios de la plaza del Sarmental, y entre los responsables del Cabildo catedralicio y las autoridades borbónicas. En segunda instancia, se ha recogido información en los libros de Redondo de dicha catedral, rastreando el pago efectivo del alquiler de dichos edificios. El catastro del marqués de la Ensenada permite acceder a las medidas de los inmuebles ${ }^{7}$ y el legajo 977 de Justicia Municipal a la descripción de sus estancias y dependencias, así como al mobiliario, ajuares y pertrechos que en ellas estaba dispuesto ${ }^{8}$. De los gruesos volúmenes de los protocolos notariales proceden también algunos documentos complementarios sobre el devenir vital de don Pedro Tomé y doña Josefa Carrera9. En el AMB es posible consultar un magnífico documento, elaborado en 1777, del que se extrae una prodigiosa información sobre esta problemática $^{10}$.

(2002), págs. 429-458, y «Familia, hogar y vivienda en Burgos a mediados del siglo XVIII. Entre cuatro paredes, compartiendo armarios, camas, mesas y manteles», Investigaciones Históricas, 22 (2002), págs. 165-211.

6 ACCB. Actas Capitulares (AC). Libros de Registro (LR) 108-115. Cabildos (1762-1782).

7 Archivo de la Diputación Provincial de Burgos (ADPB). Catastro de Ensenada (CE). Libros de lo Personal (LP) o Memoriales de laicos y eclesiásticos, libros 344-349 (mediados de 1751). La casa 123 tenía 9,5 metros de altura y $811,2 \mathrm{~m}^{2}$ de suelos útiles para la convivencia (31,5 metros de largo por 12,9 metros de ancho en cada planta). Con los entresuelos y los desvanes sumarían en total $1622,4 \mathrm{~m}^{2}$ aproximadamente. La casa 123 bis era menos espaciosa aunque su altura era idéntica. Las plantas disponían de, más o menos, 287,6 $\mathrm{m}^{2}$ de suelos útiles para la corresidencia (31,4 metros de largo por 4,6 metros de ancho en cada una de las dos plantas) — 575,2 $\mathrm{m}^{2}$ con los entresuelos y los desvanes—. En resumen, el hogar de Pedro Tomé y Josefa Carrera posibilitaba el acceso a 1.098,8 $\mathrm{m}^{2}$ de suelos útiles para la convivencia, sobre los cuales desarrollaron, entre 1725 y 1764, su activa y laboriosa existencia. ADPB. CE. LP. Memorial de Pedro Tomé González. Libro 347, ff. 92-96 (28 de junio de 1751).

8 Archivo Histórico Provincial de Burgos (AHPB). Protocolos Notariales (PN) y Justicia Municipal (JM), legajo 977. Se citarán de manera oportuna cada uno de ellos cuando sea conveniente.

9 No sólo para el problema del intento de desalojo de la vivienda del Sarmental sino para otras cuestiones de singular interés. AHPN. PN. Múltiples legajos que serán citados de forma pormenorizada en el discurso de las notas a pie de página.

10 Archivo Municipal de Burgos (AMB). Histórica. HI-5269 (1777). «Dilijenzias Practicadas a Instan-

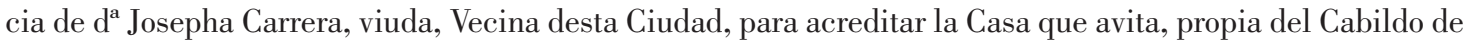
la Santa Iglesia Metropolitana desta Ciudad». 


\section{II. ¿Litigio entre covachuelas o mero asunto de alquileres?}

La necesidad de reedificar era una exigencia que devenía de los intereses de sus propietarios, cualesquiera que fuesen - laicos o eclesiásticos-, y de las directrices del Gobierno borbónico, empeñado en «hermosear» ${ }^{11}$ las ciudades del Setecientos. El Concejo era el brazo ejecutor de la política gubernamental. Los graves peligros que se suscitaban a sus ocupantes, consecuencia de los deterioros infringidos por el paso del tiempo y el impacto de la climatología, obligaban a invertir notables proporciones de dinero en su reparación, preocupaciones que eran aprovechadas por sus legítimos propietarios para incrementar el monto de los alquileres ${ }^{12}$.

\section{II.1. LA EXPLOSIÓN DEL CONTENCIOSO URBANíSTICO}

El espinoso conflicto surgido entre el Cabildo y los Tomé comenzó en marzo de 1763. El Cabildo catedralicio estaba empeñado en reedificar sus propiedades inmuebles urbanas, bastante deterioradas por la climatología, el uso intensivo y el paso del tiempo, como lo estaba buena parte del caserío burgalés. La rehabilitación de edificios fue un proceso inserto en una monumental exigencia devenida de sus propios intereses «capitalistas» — como inversores en infraestructuras urbanas - y de los proyectos borbónicos tendentes a embellecer y regenerar las ciudades preindustriales ${ }^{13}$.

El 10 de marzo de 1763, el Cabildo ordinario de la catedral decidía que las «Casas a la plazuela del Sarmental [...] se igualen con las nuevas y a la en que vive don Pedro Thomé se haga la cítara de ladrillo» ${ }^{14}$.

11 ACCB. AC. LR 114. Cabildo del 1 de junio de 1767, f. 160. Carta de don Miguel Bañuelos, intendente y corregidor, al Cabildo catedralicio.

12 Lo acontecido alrededor de las casas 123 y 123 bis de la plaza del Sarmental no hubiera pasado de ser un mero trámite más en el proceso de rehabilitación de los inmuebles propiedad del Cabildo catedralicio de no haber mediado la compleja personalidad de sus arrendadores, Pedro Tomé y Josefa Carrera, y las actividades profesionales que se desarrollaban en dichos edificios. El litigio escapó de los estrechos límites de Burgos para llegar a las mesas de los despachos de los altos cargos de la Administración del Estado. Los caudales del rey corrían grave peligro en la ciudad castellana.

13 Una anecdótica actuación urbanística degeneró en un conflicto de Estado, por la renuencia de Pedro Tomé y Josefa Carrera a que se tocara su vivienda. Véanse los análisis de Lena Saladina IgLESias Rouco, Arquitectura y urbanismo en Burgos bajo el Reformismo ilustrado (1747-1813), Burgos, Caja de Ahorros Municipal de Burgos, 1978, y René Jesús Payo Hernanz, Arte y sociedad en Burgos en la segunda mitad del siglo XVIII, Burgos, Institución Fernán González, 2003.

14 El diputado de Hacienda del Cabildo, el canónigo Sota, señaló ante sus «compadres» capitulares que «las tres casas que se están fabricando a la plazuela del Sarmental se concluirán en breve y que , para evitar goteras, según se ha experimentado este año, parece preciso, como se premeditó quando se resolvió edificarlas, igualar con dichas casas el tejado de la casa de la esquina que habita don Gregorio Bernáldez, 
Una semana después, el día 17, se hizo público en el Cabildo un memorial de don Pedro en el que «pide se le conceda más tiempo para buscar casa» ${ }^{15}$. «La edad nonagenaria en que se halla» ${ }^{16}$ y los «continuos havituales afectos que padece» ${ }^{17}$ determinaban que «qualquier remoción le era peligrosa». Aducía, además, que «expezialmente haviendo vivido en ella desde que se rehedificó, que abra como cosa de quarenta años». El abandono de dichas casas le generaría innumerables perjuicios. Tomé había buscado otra residencia, pero concluía que era un hecho indudable la carencia de inmuebles idóneos ${ }^{18}$. Sus responsabilidades «no le permiten por ningún respeto fallar al servizio de SM en el abandono de sus intereses y seguridad de sus reales haveres, que forzosamente se ha de seguir pasándose a casa no oportuna para su buena administración», y menos en un tiempo tan limitado y de forma tan precaria ${ }^{19}$.

De una manera ambivalente, don Pedro Tomé manejaba con la habilidad que siempre le caracterizaba el presunto «perjuizio de la Real hazienda» infringido por el Cabildo y el más que previsible deterioro de su modo de vida, como consecuencia de «las incomodidades de su persona y familia [...] ciñéndose a una limitada habitazión por dexar la restante para las ofizinas de su despacho, pues estas se hallan colocadas en la casa contigua a la que habita». Otra solución que también había pasado por la cabeza de don Pedro era, «con no poco dolor paternal, pasarse a habitar a la casa propia que tiene en la calle de los Avellanos, exponiendo a que el habitador, su hixo don Antonio, se vea en la calle ${ }^{20}$. Sopesadas todas las circunstancias — cambiar de lugar de residencia y

levantándole como siete pies, y de la que arrima a la muralla en que vive don Pedro Thomé, haciendo en esta la fachada a dicha plazuela de ladrillo para mayor permanencia, la que corresponde al medio día y cae a la esgueva, y demoler una caballeriza tras de la expresada casa y pajar para que el patio que queda entre dichas casas tenga ventilación y expediente para las aguas, lo que se podrá executar sin que dicho don Pedro desembarazase la referida casa». El Cabildo aprobó dichas medidas y «cometió a los Señores Diputados de hazienda para que, avisando a dho don Pedro Thomé, desocupe la casa». ACCB. AC. LR 109. Cabildo del 10 de marzo de 1763 , f. $369 \mathrm{v}$.

15 ACCB. AC. LR 109. Cabildo del 17 de marzo de 1763, f. 373.

16 Don Pedro Tomé fue bautizado en Melgar de Fernamental (Burgos) el 7 de julio de 1680. Dato extraído de Ismael García Rámila, «Del Burgos de antaño. Los Tomé. Antecedentes familiares», Boletín de la Comisión Provincial de Monumentos, t. V (1939), pág. 208.

17 A las dolorosas retenciones de orina habría que añadir sus graves padecimientos de gota, en su variante más extenuante, la podagra, afecciones que agriaron su carácter y generaron abrumadores momentos de ira e incomodidad.

18 ACCB. AC. LR 109. «Memorial» de Pedro Tomé inserto en el Cabildo del 17 de marzo de 1763, ff. 373-374. Señalaba Tomé que en Burgos había «pocas desocupadas al presente y ninguna cómoda para el manejo de las dependencias que la piedad del Rey se ha servido poner a su cargo, que son la Tesorería de Bullas de la Santa Cruzada, la administración del papel sellado y la grazia de la casa excusada».

19 Ibidem, f. 374.

20 La casa de Avellanos fue adquirida en 1734 a su propietario, el convento de Santa Ana de San Sebastián. AHPB. PN. Juan Antonio Fernández Guilarte. Legajo 7.004 (10 de julio de 1734), ff. 639-664. Don 
albergarse en la citada calle de los Avellanos-, Tomé declinó finalmente dicha opción ${ }^{21}$.

La condescendencia del Cabildo prorrogó hasta el primero de agosto de 1763 el inicio de las obras de rehabilitación del edificio, pero señalando que «la cavalleriza y [la] pajera son independientes de la casa en que vive». Tomé se vio sorprendido por la orden del Cabildo para que el 16 de marzo «dexase desocupada las caballerizas y desembarazado el paxar porque se había mandado diese prinzipio a demoler las paredes de una y otra ofizina». Don Pedro se quejaba amargamente de que «quien ha merecido tantos honores, pensase en una providencia phisicamente imposible, como lo es el remover los axuares de las expresadas piezas y buscar otras para su acomodo en el discurso de ocho horas que restaban al día», circunstancia «poco decorosa y [que] degenera de la piedad con que VJ se ha servido mirar a otros inquilinos ${ }^{22}$.

La rehabilitación de la plazuela del Sarmental tiene en la reedificación «de las tres Casas que se han de hacer Nuebas, De las quatro biejas que oy Existen $»^{23}$ un hito esencial en la mejora de dicho espacio urbano. El maestro de obras Santiago Pérez ${ }^{24}$ se hizo cargo de la ejecución — por 70.000 reales-. Entre noviembre de 1762 y fin de septiembre de 1763 se ejecutaron los quehaceres constructivos, hasta finalizarlas «llabe en mano». En marzo de 1762, el Cabildo indicaba que tres de sus casas en el Sarmental «necesitan reparos considerables, que pasarán de 10.000 reales, por lo que les parezía que atendiendo a dichos gastos y a los que en adelante se podía pensar de hacer en dichas casas y de la inmediata a la que pega con la muralla otras proporcionadas para individuos del Cabildo» ${ }^{25}$.

Pedro sufrió dramáticamente por la desaparición — huido de la justicia— de su primogénito y mano derecha, Juan Manuel, en 1755, la muerte del benjamín, Fernando, en 1756, y por las tensas relaciones con el clérigo de la familia, Pedro Celestino, arcediano de Burgos en el Cabildo catedralicio. Le resultaba inimaginable perjudicar a su hijo Antonio, convertido, a la sazón, en su lugarteniente, heredero y copartícipe de los intereses empresariales del hogar.

${ }^{21}$ La casa de Avellanos no era, según Tomé, «por ninguna circunstancia apta para el manexo de las Reales dependenzias de su cargo». Las citas textuales de este párrafo en ACCB. AC. LR 109, Cabildo del 17 de marzo de 1763, ff. 373-374. En la práctica, don Pedro se negaba a abandonar ni un solo metro cuadrado de dicha vivienda.

${ }^{22}$ Lo más grave era, por encima de sus carruajes, animales y atalajes, «las propias consecuenzias contra la Real hazienda, respecto de que demolidas estas paredes quedan expuestos sus caudales al insulto, y los enseres de granos a muchas perjudiziales contingencias, como se haze visible». Ibidem. Sobre los carruajes, Francisco SAnz de la Higuera, «Una estancia doméstica que se mueve. Entre las calles y las casas de Burgos a mediados del siglo XvIII», Cuadernos de Investigación Histórica, 21 (2004), págs. 469-506.

23 AHPB. PN. Juan Antonio Fernández Guilarte. Legajo 7.027 (13 de junio de 1762), ff. 392-393.

24 ADPB. CE. RP. Libro 347 (30 de abril de 1751), ff. 357-358.

25 ACCB. AC. LR 109. Cabildo del 18 de marzo de 1762, f. 246. 
A este fin, y sin dilación alguna, el Cabildo encargó al maestro Bastigueta ${ }^{26}$ que hiciese «traza y condiciones», para que fueran «suficientes y mui cómodas cada una de ellas para qualquiera señor capitular». El coste se reguló en 66.000 reales, «sirviendo los materiales que ahora tienen para su redificazión» ${ }^{27}$. Los miembros del Cabildo catedralicio querían amortizar las inversiones inmobiliarias con alquileres que hicieran más atractivo colocar capitales en lo urbano — merced a arrendamientos crecientes_ que en la deuda pública del Estado o en los préstamos hipotecarios privados.

Ya fuera para proteger los intereses de la Hacienda pública, de la que era un evidente beneficiario, o para impedir que se le despojase de su confortable, envidiable y céntrica vivienda en la plazuela del Sarmental, don Pedro Tomé se negó reiteradamente a abandonar el edificio que ocupaba desde 1723. Los $1.099 \mathrm{~m}^{2}$ de suelos útiles que le proporcionaban los inmuebles 123 y 123 bis del Sarmental (1725-1763) eran bastantes más que los $500 \mathrm{~m}^{2}$ de la casa de Avellanos $^{28}$. Como se descubre en otras ocasiones, los 960 reales que abonaba al Cabildo catedralicio por el alquiler de los dos edificios del Sarmental quedaban, en parte, compensados con los 770 reales que se le pagaban por el arrendamiento de la casa de Avellanos ${ }^{29}$. El análisis del ciclo vital del hogar de Pedro Tomé y Josefa Carrera, a través de los diversos hitos que la documentación ha puesto en nuestras manos, nos permite entrever una época caracterizada por un

26 ADPB. CE. RP. Libro 344, f. 986. Véanse Lena Saladina IgLESIAs Rouco, «En torno a la arquitectura burgalesa de la segunda mitad del siglo XVIII y su problemática profesional», en Actas del IX Congreso Español de Historia del Arte, León, Universidad de León, 1992, págs. 43-52, «En torno a la arquitectura burgalesa de la primera mitad del siglo XVIII: el maestro Francisco de Bazteguieta», Boletín del Seminario de Estudios de Arte y Arqueología, 59 (1993), págs. 405-422, y Lena Saladina Iglesias Rouco y María José Zaparaín YÁNEZ, «El proceso de construcción en Burgos, 1700-1765. Aportación a su estudio», en Actas del I Congreso Nacional de Historia de la Construcción, Madrid, Centro de Estudios y Experimentación de Obras Públicas, 1996, págs. 283-290.

27 Los cálculos de beneficio «capitalista» fueron explícitos y manifiestamente inflacionarios: «[...] que al presente reditúan dichas casas, vajados 550 reales en que se regulan los reparos que en cada un año se necesitarán no haciéndose nuevas, sólo 631 reales, que con 900 que importarán los réditos de dichos 6.000 ducados, a uno y medio por ciento, componen 1.621 reales, y arrendando dichas casas a 60 ducados, por la cercanía de la Iglesia, sitio y comodidades deliniadas en ellas, resulta de beneficio 359 reales en caso de no tener más coste que el referido». ACCB. AC. LR 109. Cabildo del 18 de marzo de 1762, f. 246. Véanse los comentarios de Jesús Bravo Lozano, Familia busca vivienda (Madrid, 1760-1800), Madrid, Fundación Matritense del Notariado, 1992, págs. 181-195.

28 ADPB. CE. RP. Libro 347, ff. 92-96.

29 El alquiler de los edificios de la plaza del Sarmental en ACCB. LR (1725-1762) y ADPB. CE. RP. Libro 347, ff. 92-96. El arrendamiento de la casa de Avellanos en AHPB. PN. Legajo 7.005 (28 de enero de 1736), f. 75 - 750 reales/año, por dos años, a don José Cazorla, administrador general de la renta de aguardientes y licores -, legajo 7.006 (29 de abril de 1737), f. 26 - 600 reales/año, por tres años, a don Manuel Bermúdez -, legajo 7.015 (16 de enero de 1747), f. 42 - 495 reañes/año, por cuatro años, a don Manuel Bárcena - y legajo 7.015 (31 de mayo de 1749), f. 249 - 770 reaels/año, por nueve años, a don Pedro Martínez de Armendáriz, administrador de las Reales Tercias. 
creciente número de las personas sujetas a corresidencia (1725-1755) y una segunda etapa marcada por el paulatino abandono del hogar por parte de los hijos, que se independizan ${ }^{30}$.

La confirmación oficial de las decisiones del Cabildo quedó escriturada el 23 de marzo de 1763. El notario secretario capitular del deán y Cabildo, en primera instancia, y el escribano del número Jacinto Álvarez, después, rubricaron el proceso. Se dieron plenas facultades a don Ramón de Larrínaga, don Andrés Ruiz Cotorro y don Gregorio de la Sota para que compareciesen ante el Alcalde Mayor, «u otro qualquiera Juez Competente, pidiendo se libre despacho en forma a efecto de Justificar con Citación de Dn Pedro Thomé, Vecino de dha Ciudad, la necesidad de la obra que hai que hacer y está proyectada en la Casa que habita [...] a la plazuela del Sarmental». En todo momento, los responsables capitulares aducían la legalidad de sus decisiones — dada «la Certeza y necesidad de esta obra» — y minimizaban el impacto del desalojo que pretendían «por la mucha Comodidad y extensión de la que tiene propia el expresado Dn Pedro Thomé a la Calle de los Abellanos [...] mui Capaz para evaquar las Condiciones que tenga a su Cuidado y de bastante buque para acomodar toda su familia en mejor forma» ${ }^{31}$.

Los argumentos del Cabildo estaban decididamente dirigidos a desmontar de manera categórica la respuesta de Tomé y a corroborar que su propiedad del Sarmental «al presente necesita de Varios reparos por cuia Causa será preciso que el mencionado Inquilino la dexe con la maior brevedad». En su apoyo, abundaba el Cabildo en las calidades del inmueble de Avellanos ${ }^{32}$.

30 Entre 1726 y 1732 nacieron sus hijos, todos varones —Juan Manuel (1726), Pedro Celestino (1727), Diego (1728), Antonio Felipe (1730) y Fernando (1732)—. En 1751, el «memorial» catastral de don Pedro significa la existencia de un hogar múltiple del tipo (5b)8, según la terminología de la Escuela de Cambridge, con la presencia del matrimonio principal, don Pedro y doña Josefa, una pareja secundaria, don Juan Manuel y su cónyuge, el vástago menor, Fernando, tres criadas y un cochero. ADPB. CE. RP. Libro 347, f. 92. En 1763, un testigo del Cabildo catedralicio señaló, en el expediente de desahucio de Pedro Tomé, que éste no mantenía en el Sarmental una dilatada familia dado que en ese momento «se reduze al matrimonio, dos Criadas y dos criados». AHPB. PN. Jacinto Álvarez. Legajo 7.118/1 (26 de marzo de 1763), f. 80v. Ello queda confirmado en el inventario post mórtem de don Pedro. AHPB. JM. Legajo 977 (14 de julio de 1764), ff. $21-127$.

31 AHPB. PN. Jacinto Álvarez. Legajo 7.118/1 (26 de marzo de 1763), ff. 73-84.

32 De ella se decía que «es de doble Latitud y Longitud que la que al presente habita y que está Sita en el Centro del Lugar y mui contigua a otras que viven Caballeros mui distinguidos como en que en ella han vivido Sujetos que han tenido bastantes dependencias, hallando bastante comodidad y anchura para su Despacho; Y custodiándose en ella los Caudales de S. M., procedentes de las Bullas, y en Igual forma y bien Cierto de la seguridad la habitó Don Antonio Gonzalo, Administrador de las Reales Rentas y del Tabaco, hallando Comodidad para su espaciosa Oficina y para Custodiar los Caudales de S. M., en cuia Casa hubiera permanecido a no haberle precisado a desampararla el expresado Thome con la Causa de que la habitase su hijo [don Antonio Tomé], que la habita al presente, teniendo en ella una gruesa Lonja de Cacao, Azucar, Canela y otros géneros». AHPB. PN. Jacinto Álvarez. Legajo 7.118/1 (28 de marzo de 1763), ff. 74-83. 
Una segunda puntualización indicaba que «es público y notorio que tiene dha Casa [se refiere obviamente al inmueble de Avellanos] Crecidas Troxes, capazes de mucho grano que acopiar en ellas con motivo de Varias Administraziones que tiene». La solidez de esa casa era contrastada una y otra vez con su propiedad del Sarmental, de la que, en apoyo a sus tesis reedificatorias, se decía que «tiene todas sus paredes de Emplenta, compuestas de palo y hieso, descascadas con la continuación de las Aguas $»^{33}$.

El Cabildo catedralicio materializó sus propuestas en un cuestionario de seis preguntas que se intentó hacer llegar a manos de don Pedro Tomé en varias ocasiones. Dichas «dilixencias» chocaron directamente con su renuencia a recibir al escribano del tribunal eclesiástico. Jacinto Álvarez llamó, en primera instancia, a la puerta de la casa del Sarmental «siendo como las doze de oy dho día veinte y quatro de Marzo de mill Setecientos Sesenta y tres». Dio recado a uno de sus criados «en orden a que expresase al dho Dn Pedro si le podía hablar dos palabras». La escena consiguiente fue impactante:

Salió dho Criado diciendo entrase en un quarto (como lo hize) y haviendo encontrado en el a $\mathrm{D}^{\mathrm{a}}$ Josepha Carrera, su Muxer, y hecho la relación atentamente de mi llegada a allí, y que necesitaba ver al expresado Dn Pedro thome, y respondídome no se podía estar con dho su marido y que por lo mismo la manifestase lo que se me ofrecía. Desde luego expresé a la mencionada $\mathrm{D}^{\mathrm{a}}$ Josepha sustancialmente el contexto del auto antecedente y del pedimento que lo motiva. Enterada la suso dha me bolbió a responder no se podía estar con el dho su Marido y que me bolbiese el día Sábado veinte y seis del corriente y ora de las nueve de la mañana que ya tendría noticiado al dho su marido mi recado y encargo ${ }^{34}$.

En efecto, Jacinto Álvarez, a la hora y día señalados, «con corta diferencia», accedió de nuevo a las estancias de la casa en litigio. Allí se encontró con doña Josefa y con Domingo Merino. En esta segunda ocasión se le despachó otra vez con la excusa de que «no podía estar con el dho su marido porque estaba sosegando en fuerza de no haverlo podido hazer en la noche por haber experimentado un total desasosiego con el accidente de supresión de orina que padece». El escribano entregó a doña Josefa «copia de los seis Capítulos» que le remitía el Cabildo y fue despedido «diciendo me volviese a las tres de la tarde

33 Según los responsables capitulares, la casa de su propiedad era una ruina, mientras que la mansión propiedad del arrendador Tomé era un dechado de virtudes. El desalojo era imprescindible, tesis que la parte contraria no compartía en absoluto. Las espadas estaban en alto y cada uno de ellos, arrendador y arrendatario, se enfrentaban a un pleito de dudosas consecuencias y espinosas circunstancias. Ibidem.

34 AHPB. PN. Jacinto Álvarez. Legajo 7.118/1 (28 de marzo de 1763), ff. 75-76. 
de oy dho día para poder estar en Persona con el dho Dn Pedro». A las tres de esa tarde —y era la tercera «Dilixencia»—— regresó el escribano al Sarmental. Al poco tiempo, bajó el susodicho Merino «diciendo [que] su Amo [...] no podía vaxar por estar mui depriesa despachando el correo de las mulas y dando expediente a diferentes Reales órdenes». A la sugerencia del escribano de esperar pacientemente «todo el tiempo que gustasen», se le indicó que «no tenía que aguardar porque sería mui tarde quando pudiese concluir dho Dn Pedro thome, su Amo» ${ }^{35}$.

El Cabildo de la catedral esgrimió en su defensa, con fecha del 28 de marzo, las opiniones de varios testigos ${ }^{36}$, los cuales respondieron a los seis interrogantes en los siguientes términos. El primer asunto describía la casa de Avellanos,

[...] en la que abita actualmente Dn Antonio, su hixo», [vivienda] que está hermoseada y tiene su frontis de sillares y cítara de Ladrillo y lo mismo su trasera, de doble latitud y lonxitud que aquella [la de Sarmental $]^{37}[\ldots]$ sita en el Centro de esta ciudad, mui contigua y cercana a la del Marqués de Fuente pelaio y Conde de Villariezo y en frente de la que vibe el Sor Marqués de Espinardo, Intendente y Correxidor [...] y de otra del que posehe dn Jerónimo Gutiérrez, Dueño y Señor de Báscones del Agua, que lleva en arrendamiento Dn Francisco de la Infanta, Comerciante de Grueso y de los más acaudalados de esta ciudad ${ }^{38}$.

Dicho inmueble se hallaba, según el quinto testigo, «en el Centro de el Pueblo en calle real y pública, contigua a otras que viben Caballeros de la primera distinción con títulos de Conde y Marqueses» ${ }^{39}$. La casa de Avellanos,

35 El pulso entre los inquilinos de la casa 123 del Sarmental y el Cabildo, con el escribano como convidado de piedra, adquirió un aspecto endiablado. El administrador general de la Santa Cruzada se negaba, de forma obstinada, a acatar las decisiones de las autoridades eclesiásticas. AHPB. PN. Jacinto Álvarez. Legajo 7.118/1 (26 de marzo de 1763), ff. 75-76.

36 Los testigos fueron el maestro de obras Francisco de Bastigueta, don Ventura Calvo, alguacil mayor de Cruzada, don Joaquín de Riofranco, presbítero capellán en el Hospital de la Concepción y beneficiado en San Román, don Francisco Gil Espiga, presbítero capellán del número en ca Catedral y el Hospital de la Concepción, don Juan Antonio Díez Gómez, cura beneficiado en San Lorenzo, y Manuel del Campo, maestro de obras y alarife de la ciudad. En resumen, dos profesionales de la construcción, un burócrata eclesiástico y tres clérigos.

37 Ventura Calvo señaló que dicha casa «es de más buque que en la que actualmente mora dho Dn Pedro como también de más fortaleza». AHPB. PN. Legajo 7.118/1 (26 de marzo de 1763), f. 78v.

38 Don Ventura, muy lenguaraz y apasionado en sus respuestas, añadió que era «uno de los de más rumbo que ai en esta dha ciudad». AHPB. PN. Legajo 7.118/1, f. 78.

39 AHPB. PN. Jacinto Álvarez. Legajo 7.118/1 (26 de marzo de 1763), ff. 81-82. En las inmediaciones se hallaba la casa del conde de Villariezo «y a corta distancia la de las Quatro torres en que está colocada la Real Contaduría desta ciudad y su Provincia y la en que se adeudan los Reales tributos de Alcabalas, cientos y millones de ella, propia del Sr Dn Francisco Antonio de Cuellar, del Consexo de S. M. y uno de sus directores de las Reales rentas». 
propiedad de Pedro Tomé, había sido residencia de individuos de notable alcurnia $^{40}$, situación que impugnaba las alegaciones de Tomé ${ }^{41}$. Pedro Tomé consideraba que su casa de Avellanos era peligrosa porque podían serle arrebatadas las crecidas cantidades de dinero que manejaba de la Santa Cruzada y del papel sellado.

A la segunda cuestión de las seis planteadas por el Cabildo, los testigos también respondieron con vehemencia y de forma decidida a favor del arrendador, es decir, de los irritados eclesiásticos capitulares. La casa propiedad de Tomé en Avellanos «tiene buenas troxes para mucho grano en que pone dho Dn Antonio lo que percibe de diferentes Administraziones que corren a su cargo» ${ }^{42}$.

El tercer asunto a dirimir era la situación estructural de la casa del Sarmental. Los testigos señalaron que tenía «todas sus Paredes de emplenta, compuestas de Maderaxe y Yeso, sumamente deteriorada la madera y casi podrida, y las llanillas de afuera descascadas, en tal disposizión que a poco agua que les llegue y azote se repasan asta lo interior ${ }^{43}$. Directamente relacionado con todo ello estaba el cuarto capítulo analizado. El contraste entre las casas 123 y 1243 bis del Sarmental y las «tres que nuevamente han reedificado y construido» les parecía a los testigos fuera de toda duda, «por la mucha más elebazión que tienen dhas Casas nuebas». Esa diferencia de altura iba en detrimento no sólo de la arrendada por Tomé sino también de las recientemente erigidas. El azote de las aguas castigaba la implenta de ambas y producía infectas humedades exteriores e interiores. Al disponer las casas nuevas de un alto más que la ocupada por Tomé, y estar «los tejados [con] mucha más elebazión», se generaba, según el Cabildo y los testigos, «una grande fealdad y deformidad [...] [por] com-

40 «...] frente de dha Casa de Dn Pedro thomé vibe el Sr Marqués de Espinardo, Intendente que ha sido de esta dha ciudad y su Provincia en cada propia del Mayorazgo de los Zapatas y en la misma fila se allan dos Casas propias y correspondientes al que posehe dn Jerónimo Gutiérrez Salamanca, Dueño del término redondo de Báscones del Agua». Ibidem, f. 83.

${ }_{41}$ Un ejemplo sobresaliente, argumentaba el Cabildo, era lo ocurrido con don Antonio Gonzalo del Río, administrador de las Reales Rentas del tabaco, quien «vibió mui contento en dha Casa por haver tenido en ella comodidad y anchura, no sólo para los oficiales que mantenía para su despacho sino para tener asegurados los Caudales de dha renta y almacenes para los tabacos, Plomos, Perdigones y Alcor». El testigo cuarto añadió que la administración de la Renta de tabacos tenía un «crecido número de Oficiales y Personas indispensables al basto manexo de este ramo». Ibidem, f. 81.

42 La casa de Avellanos servía para «cargar recuas de pan propio de sus tráficos, que según está reputado en esta dha ciudad son Crecidos, como también de que trata y comercia de grueso con Cacao, azúcar y otros diferentes Géneros y para esto tiene su correspondiente Despacho». Ibidem, ff. 77-84.

$43 \mathrm{El}$ aspecto esencial era la «fealdad» del conjunto, consecuencia de la «dibersidad de materiales». La casa del Sarmental tenía hasta el primer suelo el paredón de mampostería y desde allí hasta el tejado emplenta de yeso y madera, con las llanillas descascadas. El contraste con el edifico de Avellanos era rotundo. Sus fachadas eran, hasta el primer piso, de sillería y hasta el tejado de ladrillo, muy bien conservados los materiales. Ibidem, ff. 77-84. 
ponerse de dibersos y Distintos materiales» y una abrumadora afección de la climatología (las aguas y los fríos que castigaban a la gélida ciudad castellana).

Otro de los asuntos más controvertidos fue el auscultado en la quinta materia. Los testigos, al unísono, señalaron que la caballeriza, la pajera y otro cuarto ocupados por Tomé eran estancias que «no corresponden a la Casa que abita y si a las nuevamente Construidas, tanto por no tener, como no tienen, puerta para su manexo por la Casa en que vibe como por tener precisión de entrar por las expresadas nuebas» ${ }^{44}$. La acusación, por la presunta usurpación ilegal de tales dependencias, sería un fiel reflejo de la falta de escrúpulos de Tomé y de la paciencia sin límites del Cabildo, quien, a pesar, de ser conocedora de tan turbia ampliación del espacio ocupado, no había denunciado tales hechos y si contemporizado con el anciano arrendador.

El último aspecto, el sexto, acusaba abiertamente a Pedro Tomé de deslealtad y casi de infamia. El Cabildo catedralicio y los testigos trajeron a colación que fuera Tomé quien solicitara años atrás, mediante un «memorial», reparos en las paredes de la casa alquilada. El testigo primero, el maestro de obra Francisco de Bastigueta, indicó que Tomé

$[\ldots]$ al tiempo que se dio principio a rehedificar y construir dhas Casas [nuevas] le manifestó que toda la fila de Casas se debía de hazer de cítara de Ladrillo y que entonzes quedarían mui buenas [...]. Dixo tiene entendido que en un tiempo sin que haga memoria del que fue pretendido el referido dn Pedro thome el que se hiciesen las paredes de la casa en que vibe de cítara de Ladrillo y que para ello se dio memorial a dhos Señores Deán y Cavildo ${ }^{45}$.

En efecto, en noviembre de 1744, fue leído en el Cabildo un «memorial» de Tomé en el que exponía «que la casa en que vive al Sarmental se halla tan maltratada que necesitan repararse los tejados», quehacer al que se unían igualmente labores de mantenimiento en «una puerta prinzipal que necesita también de reformas» ${ }^{46}$.

Acabada la deposición de los testigos, el Cabildo elevó «la Información antecedente, Pedimentos y dilixencias que la motivan» a conocimiento del alcalde mayor de Burgos el 29 de marzo de 1763, solicitando la ejecución del desalojo

44 AHPB. PN. Jacinto Álvarez. Legajo 7.118/1 (26 de marzo de 1763), ff. 77-84.

45 AHPB. PN. Jacinto Álvarez. Legajo 7.118/1 (26 de marzo de 1763), f. 77.

46 ACCB. AC. LR 105. Cabildo del 13 de noviembre de 1744, f. 188. En marzo de 1758, se documenta otra petición de reparos en la casa del Sarmental, argumentada también por el Cabildo como signo evidente de mala fe por parte de Pedro Tomé en este turbio affaire. 
y vía libre para la reedificación de la casa 123 de su propiedad ${ }^{47}$. El Cabildo puntualizó que en modo alguno era su objetivo

[...] molestarle ni vexarle ni a que en los caudales de S. M. haia mala versación sino sólo a hacer las obras precisas en la referida casa, pues si advirtiéramos que de mantenerse Thomé en ella se siguiese beneficio a el Real herario, por no encontrar otra de igual seguridad y comodidad para el desempeño de las comisiones que S. M. le tiene confiadas, sacrificaríamos con gran gusto nuestros intereses y utilidades en obsequio de tan glorioso fin ${ }^{48}$.

En agosto de 1763, el maestro de obras responsable de la erección de las casas nuevas de la plaza del Sarmental, Santiago Pérez, daba «quenta del atentado de Thomé impidiendo arrendar la [casa] inmediata a la que habita» ${ }^{49}$. En septiembre se leyó un «memorial» de Tomé en el que pedía se le arrendara sin dilación

[...] una de las casas reedificadas en la plazuela del Sarmental, en la casa contigua a la principal que habita [porque] se ha visto precisado a destrecharse y reducirse a esta y mudar de aquella los diversos despachos y oficinas, [dado] que con la debida separación deben girar los diferentes negocios y encargos del Real Servizio para con confundirse unos con otros.

Tomé solicitaba del Cabildo, «estando ya enteramente concluida la nueva obra de la referida casa continua, desea extender a ella su vivienda para mayor comodidad de los dependientes de la administrazión». Aceptaba pagar las rentas que el Cabildo señalara para las nuevas casas recién edificadas ${ }^{50}$.

El día anterior, en la jornada previa al momento de la entrega formal de las llaves de las tres casas, se produjo un grave altercado, «entre nueve y diez de la mañana», en el que se vio involucrado uno de los oficiales de Pedro Tomé. El maestro de obras, bastante dolido por las actitudes y desprecios a que había sometido por Tomé, «había dejado cerrado en una pajera y caballeriza [a] un co-

47 AHPB. PN. Jacinto Álvarez. Legajo 7.118/1 (29 de marzo de 1763), f. 84.

48 El Cabildo añadía que «siendo público que hay otras muchas casas en esta Ciudad más a propósito para el fin expresado, y especialmente la que tiene dho Thomé propia suia a la calle de los Avellanos, no es justo que por pretextar servicio a S. M. (lo que de ningún modo es) se nos sigan conocidos perjuicios». ACCB. AC. LR 109. Cabildo del 24 de marzo de 1763, f. 393.

49 Denunciaba «los embarazos que ha puesto y lo que se ha propasado don Pedro Thomé», quien se había adueñado de los entresuelos de una de las nuevas casas «sin permiso del Cavildo». Ibidem, Cabildo del 17 de agosto de 1763, f. 448.

50 ACCB. AC. LR 109. Cabildo del 12 de septiembre de 1763, ff. 461-462. 
chero y [las] mulas del mencionado su Amo» ${ }^{51}$. El empleado de Tomé solicitó a los diputados de Hacienda del Cabildo que «respecto de no tener otra salida los encerrados muebles le franqueasen la llave para tomar prompta providencia». El Cabildo cedió y entregó las llaves, pero no sin dejar constancia de su estupor y enfado. El fin de la reedificación de las dichas casas era, a la postre, «subvenir a la nezesidad de los señores prebendados que están sufriendo la incomodidad y distancia de la Iglesia, bibiendo en casas forasteras, pagando el estipendio que cada dueño señala a medida de su gusto ${ }^{52}$. Era imprescindible conseguir, «por los medios más promptos y ejecutivos», que Tomé dejara de perturbar al Cabildo con sus quejas, ocupaciones de estancias, desplantes burdos, tiranteces y desprecios, permitiera «el uso franco, libre y desembarazado de ellas» y que facilitara el arreglo de la «fea servidumbre» de los edificios y declinara en «sus altas aunque pueriles máximas» ${ }^{53}$.

En noviembre de 1763 el asunto aún tenía encrespado al Cabildo. Quedaba pendiente un asunto menor, «hacer tránsito por la puerta de la casa nueba contigua a la de don Pedro Thomé a fin de que éste usase de la caballeriza y pajar de que antes usaba». El Cabildo se negaba en redondo a pasar por dicha reforma y «se le conmina de nuevo a que abandone su uso», y que solucione el problema de fondo, es decir, «el desalojo de su casa principal». La irritación de los capitulares era tal que la inmensa mayoría se decantaba, «si fuese necesario», por iniciar un pleito judicial «riguroso en tribunal competente y legítimo», institución para lo cual no era, en absoluto, indicada la Junta de la Dirección del Excusado. Tras larga deliberación, el Cabildo concluyó que la irrupción en el affaire de las autoridades madrileñas «vulnera la inmunidad e infringe la libertad eclesiástica» ${ }^{54}$.

\section{II.2. La COnVERsión DEL intento de DESAlojo En PRoblema de Estado}

\section{El recurso a las autoridades cortesanas}

En un movimiento de inusitada osadía, el nonagenario Pedro Tomé se recluyó en su despacho a mediados del mes de abril de 1763 y redactó una ague-

51 Ibidem, f. 461. Véase Francisco SANZ DE LA Higuera, «Una estancia doméstica que se mueve...», pág. 502.

52 Ibidem, f. 461. Véase Francisco SANZ DE LA HIGUERA, «Una estancia doméstica que se mueve...», pág. 502.

$53 \quad$ Ibidem, Cabildo del 4 de noviembre de 1763, f. 487.

54 ACCB. AC. LR 109. Cabildo del 4 de noviembre de 1763, f. 487. Un problema de orden menor, entre un propietario arrendador y el tomador de un alquiler, se transformó en un espinoso asunto de Estado. Véanse las propuestas de José María Imízcoz Beunza y Oihane Oliveri Korta (eds.), Economía doméstica y redes sociales en el Antiguo Régimen, Madrid, Sílex, 2010. 
rrida carta dirigida al marqués de Fontanar, don Alonso Pérez Delgado, director general de la gracia del excusado. Su contenido no tiene desperdicio. Le recordó a su superior jerárquico quién era, es decir, su calidad de «administrador por S. M. de la grazia del excusado en todo ese arzobispado ${ }^{55}$. El relato de las vicisitudes de la ocupación de la casa de la plazuela del Sarmental es categórico.

Habrá cinquenta años que tomó en arrendamiento una casa propia del Cabildo de la Sancta Iglesia Metropolitana, la que havitó hasta que reedificó otra contigua a ella, que tomó tamvién en arrendamiento junto con la que tenía, habitando una y otra vajo de una servidumbre hasta el presente, pagando su renta por espacio de quarenta años, sin que haia havido otro inquilino después de su reedificazión.

En marzo de 1763, el Cabildo, según sus propias palabras, estaba «intentando expelerles ahora sin saber el motivo, sin emvargo de protextarse nueva obra, para lo qual havía pensado el Cabildo el año pasado demoler tres casas contiguas a la antigua que havita, dándole recado de que la desembarazase». Argumentaba Tomé al marqués de Fontanar que

[...] no penetrando entonces la cautelosa másima que ahora toca havía desocupado los despachos que estaban en el quarto principal, quedándose con las ofizinas de inferior servidumbre, esperando que se le diese, como se le havía insinuado, concluída que fuese, por lo que havia ceñido a pasar las incomodidades de su persona por aquel breve tiempo, careciendo de tener a la mano el manejo de las dependencias.

El Cabildo no se contentó con ello y había dado la orden —añadía Pedro Tomé- de que «se pasase a derrivar las paredes de la cavalleriza y pajar que tiene la casa que havita ${ }^{56}$.

La tesis de Tomé era que, «no siendo las miras del Cavildo otras que molestarle, como tamvién a su hijo ${ }^{57}$, se podía hablar casi abiertamente de un com-

55 Ibidem, Cabildo del 17 de marzo de 1763, ff. 373-374. Véanse las reflexiones de Francisco SANZ DE LA Higuera, «Las restauraciones del Consulado...», págs. 429-458, «Pólvoras, municiones, lanas, granos, bullas y papel sellado (1704-1764): don Pedro Tomé González y la hora Navarra en el Burgos del siglo XVIII», Boletín de la Institución Fernán González (BIFG), 227 (2003), págs. 375-411 y “"Estando como estamos juntos y congregados en la casa de dicha Contratación como lo acostumbramos": luces y sombras en el Consulado de Burgos», BIFG, 229 (2004), págs. 377-414.

56 Las citas textuales en ACCB. AC. LR 109. Cabildo del 17 de marzo de 1763, ff. 373-374.

57 Don Antonio Tomé Carrera se enfrentó también, cotidianamente, a múltiples problemas de rechazo y animadversión por parte del sector más reaccionario del Concejo, quien le negó en principio su calidad de hidalgo para ejercer quehaceres de regidor. 
plot no sólo contra su persona sino también contra los intereses de la monarquía y de sus más emblemáticas autoridades. El argumento del Cabildo, «queriendo hazer ver [que] la casa donde vive [don Antonio] es cómoda para su manejo, lo que no es assí», era insoportable porque «no ay en esa ciudad otra más a propósito para la administración del excusado que la que havita [se refiere obviamente a la del Sarmental]». En conclusión, urgía a las autoridades de la Corte a que presionasen «para que se le mantubiese en dicha casa [y] no se demoliesen las ofizinas de la contigua por los inconvenientes que expresava». Insistió don Pedro, por lo sensible del asunto, en que no era justo «que los caudales y efectos pertenezientes a S M de dicha grazia queden expuestos a que se extraigan, roben o tengan alguna otra mala versazión» ${ }^{58}$.

El apoyo de las autoridades borbónicas a don Pedro Tomé fue incondicional. Las órdenes al intendente y de éste al Cabildo catedralicio fueron rotundas $^{59}$. Entre el 15 y el 18 de julio de 1763 se fueron recibiendo en el Cabildo las directivas del intendente sobre «el negocio de la casa de Thomé» ${ }^{60}$, fiel reflejo de las decisiones del marqués de Fontanar del 4 de abril de 1763.

En los círculos de presión de la Corte, en los vórtices activos del clientelismo y de las redes de influencia de la administración borbónica, aún tenía un peso específico relevante la figura de don Pedro Tomé González, uno de los hombres del rey en Burgos ${ }^{61}$. Sin duda, eran aún muy valoradas y tenidas en cuenta las aportaciones de Tomé en los difíciles momentos de la guerra de sucesión, sus quehaceres como procurador mayor de la ciudad (1725-1727 y 1736-1738) y, por supuesto, su compromiso al frente de la colecturía general del subsidio y el excusado (1726-1743) y en la administración general de la Santa Cruzada (1733-1764) ${ }^{62}$, actividades realizadas a la sombra de personajes de gran renombre en la Corte como don Pedro de Astrearena, don Pedro de Iturralde, don Ventura de Pinedo, don Domingo de Carranza, don Francisco de Carrasco y, por supuesto, del «gran hermano» todopoderoso de la gestión política y económica de mediados del Setecientos, el marqués de la Ensenada, bajo cuya protectora capa se situó siempre Pedro Tomé, el aguerrido y fiel «álter ego» del entramado

58 ACCB. AC. LR 109. Cabildo del 17 de marzo de 1763, ff. 373-374.

59 Se exigía del Cabildo que «se sirva suspender por ahora la execuzión de qualquiera obra que se halle proyectada en la casa de Thomé y que éste continúe habitándola sin hazerse novedad hasta tanto que por la Dirección General de la grazia del Excusado se tome la providencia correspondiente». Ibidem, Cabildo del 24 de marzo de 1763, f. 377.

60 Ibidem, Cabildo del 15 de julio de 1763, f. 436, y Cabildo del 18 de julio de 1763, f. 439.

61 Francisco SANZ dE la Higuera, «Pólvoras, municiones...», págs. 375-411.

62 Francisco Sanz de la Higuera, «Las restauraciones del Consulado...», págs. 429-458, «Pólvoras, municiones...», págs. 375-411 y «"Estando como estamos juntos...”», págs. 377-413. 
socio-político y financiero de los navarros de la Corte madrileña en Burgos ${ }^{63}$. Aún en septiembre de 1764, una vez fallecido Tomé, la confianza de Madrid en doña Josefa Carrera era absoluta,

[...] por quanto el Exmo Sor Marqués de Squilaze, del Consejo de Estado de S. M., Secretario del Despacho Universal de Hazienda, Superintendente General del cobro y distribución de ella en atenzión a lo bien que dho mi Marido sirvió la administrazión de la gracia del excusado de este Arzobispado y a la seguridad que resulta a la Real Hazienda de que continúe este encargo su Casa ${ }^{64}$.

La exigencia de desalojo a que el Cabildo arrumbó a Pedro Tomé tenía una lectura perversa que iba mucho más allá de lo puramente urbanístico y entraba en el escabroso terreno del acoso a uno de los más notables peones del rey y de la administración borbónica en las calles burgalesas. El Cabildo catedralicio se veía empujado por las decisiones borbónicas a remediar el deterioro y la ruina de sus inmuebles y a «hermosear» el aspecto de la ciudad en la parte que le correspondía. Se trata de un Cabildo catedralicio, el burgalés, que se situó en múltiples ocasiones en la otra parte de la trinchera política, es decir, en un terreno oscurantista y en un férreo conjunto de duros enfrentamientos con las autoridades borbónicas y sus representantes políticos y religiosos en Burgos. El Cabildo catedralicio se vio envuelto en corrosivos litigios que, en última instancia, enfrentaban a todos o parte de sus componentes entre ellos y con las estrategias y decisiones de los representantes del rey. El pleito de 1743 sobre la rectoría del seminario de San Nicolás ${ }^{65}$, los enfrentamientos alrededor de la cebada para las mulas de los coches de los prebendados catedralicios ${ }^{66}$ o el aciago contencioso con el arzobispo Rodríguez de Arellano nos ponen en la pista de un Cabildo catedralicio empeñado en la defensa a ultranza de sus

63 Véanse sobre redes de influencia y clientelismo, además de la citada anteriormente, José María Imízcoz Beunza (dir.), Élites, poder y red social, Bilbao, Universidad del País Vasco, 1996, y Redes familiares y patronazgo, Bilbao, Universidad del País Vasco, 2001. Véanse igualmente Francisco Chacón Jiménez y Juan Hernández Franco (eds.), Familias, poderosos y oligarquías, Murcia, Universidad de Murcia, 2001, y el número 97/1 (1995) del Bulletin Hispanique y el número 21 (1995) de Historia Social. Para el Burgos del Setecientos, Francisco SANZ DE LA Higuera, «Pólvoras, municiones...», págs. 375-411, en especial la bibliografía citada sobre los individuos citados en el texto.

64 AHPB. PN. Juan Antonio Fernández Guilarte. Legajo 7.029 (2 de septiembre de 1764), ff. 526-527. Poco antes de su fallecimiento, Pedro Tomé se había asegurado, de manera pormenorizada, de que su viuda no quedara desprotegida y asumiera la gestión de la Santa Cruzada y del papel sellado. Ibidem, legajo 7.029 (15 de enero de 1763), ff. 85-90 y (5 de febrero de 1764), ff. 113-118.

65 Francisco SANZ de la Higuera, «Seminario de San Nicolás (Burgos, 1743): una rectoría apetecible, un litigio aborrecible», BIFG, 232 (2006), págs. 149-177.

66 Francisco Sanz de la Higuera, «Cebada, mulas, caballos, carruajes y habas. La catedral de Burgos en el Setecientos », Hispania Sacra, 116 (2005), págs. 559-588. 
fueros y autonomía frente a las tentativas de las mentes ilustradas y defensoras de las políticas regalistas y modernizadoras de la administración borbónica. Las fechas en que suceden estos últimos eventos fueron paralelas al surgimiento y «envenenamiento» del rifirrafe entre Tomé y el Cabildo. Los «castigos» que el Cabildo catedralicio, y en especial el deán Calderón de la Barca, recibieron en múltiples asuntos fueron repercutidos, a modo de vendetta asfixiante, contra Pedro Tomé y la vivienda que ocupaba en el Sarmental.

El intendente urgía al Concejo y ambos al Cabildo —en realidad, a todos los propietarios de casas de la ciudad, fueran eclesiásticos o laicos-. El Cabildo exigió a Pedro Tomé, primero, y a su viuda, después, que abandonara un edificio que pensaba reedificar. En la mayoría de las ocasiones, el inquilino se marchaba a otra vivienda, el inmueble era reconstruido y no pasaba nada en absoluto. En el affaire que analizamos, el problema superó el casco histórico de Burgos y llegó a los despachos de la Corte.

Las exigencias del intendente Bañuelos fueron habitualmente ejecutadas y años más tarde pública y privadamente festejadas. En una carta remitida por el citado Bañuelos en junio de 1767 al Cabildo catedralicio, el intendente aseveraba sus

[...] gratitudes atentas de que es tan digno [el Cabildo] por la prompta condescendencia, a quanto conduce al desempeño de las Reales Órdenes, al bien público y a la hermosura y aumento de esta Capital, pues soy testigo con elogio y aplauso de que con considerable dispendio está levantando muchas Casas y reparando otras, sin repugnancia a mis insinuaciones y sin dilatar las providencias que tanto aiudan al lucimiento de mi Ministerio y llevaré a todas partes esta memoria para exercitarme con satisfacción en su servicio y obsequio.

Estas cálidas palabras no ocultaban, sin embargo, nuevas exigencias. Bañuelos solicitaba del Cabildo «si no le fuese de grabe incomodo, de disposición para que se reedifiquen las Casas arruinadas en los solares que le pertenecen y que el aspecto corresponda a la galantería y esmero con que VJ hace todas las Cosas» ${ }^{67}$.

${ }_{67}$ ACCB. AC. LR 110. Cabildo del 1 de junio de 1767, f. 160, y Cabildo del 24 de julio de 1767, ff. 202-203. 

DE GÉNERO

El 13 de febrero de 1777 retorna a los plenarios del Cabildo la problemática de la «Casa al Sarmental, su Reedificazión, quitada a quien la havita, y su concesión al Señor Deán». Se dijo sin ambages: «[...] desde el año de mill Setecientos y Sesenta y tres está determinado por el Cavildo se uniforme la esquadra de casa que tiene en la plazuela del Sarmental inmediata a la Muralla que entonces se reedificó, lo que no ha tenido efecto por los impedimentos que se le pusieron por Dn Pedro Thomé». Una profunda espina clavada en la autoestima del Cabildo hacía emerger, de nuevo, la imperiosa necesidad de desalojar de su vivienda al administrador general de la Santa Cruzada y de suprimir el borrón que supuso «el no poder mejorarla y el desaire y detrimento de privarle de derecho que como Dueño que es de ella le compete» ${ }^{68}$.

Este segundo episodio de intento de desalojo agravó más si cabe lo espinoso y lo esperpéntico del asunto en el que se debatían una poderosa institución eclesiástica, el Cabildo catedralicio, y una viuda con un nivel de fortuna aristocrático. En primera instancia, es significativo que se persistiera en el deseo de expeler de dicho inmueble a una mujer, viuda para más señas, y además mayor de edad, es decir, a una anciana ${ }^{69}$ cargada de achaques y enfermedades ${ }^{70}$. En segundo término, es sintomático que se entregue la casa en arrendamiento al deán, que decía necesitarla. Don Juan López Cabrejas postulaba por ella, «obligándose a havitar ínterin viva la nueba que se haga en el referido sitio [y] satisfaciendo el rédito correspondiente al tanto por ziento que se regule conforme se executó últimamente con la del Señor Lectoral o más si pareciese». El Cabildo estaba decidido a practicar «quantas diligencias sean conducentes hasta poner corriente y expedita la libertad que al cavildo toca como tal Dueño que es de la

68 ACCB. AC. LR 114. Cabildo del 13 de febrero de 1777, f. 201. No se trataba ya únicamente de retornar a la reivindicación urbanística —enjugar «la deformidad que causa el aspecto público»—, sino de maquillar un tremendo sentimiento de derrota, de humillación, infringido por el alquilador, Pedro Tomé, al Cabildo catedralicio.

69 En la «Información y otras Dilijenzias Practicada a Instancia de d Josepha Carrera, viuda, vecina desta Ciudad, para acreditar que la Casa que avita, propia del Cavildo de la Sta Iglesia Metropolitana desta Ciudad», no está en ruina y no era lícito desahuciarla de su usufructo, se incorpora copia de la partida de bautismo de doña Josefa (jueves, 20 de marzo de 1692). AMB. Histórica. HI-5269 (1777). En 1777, tenía, por tanto, 85 años. Archivo Diocesano de Burgos (ADB). San Román. Libro de bautismos (20 de marzo de 1692), f. 165. Sobre la vejez y sus problemáticas en el Antiguo Régimen, véanse especialmente Francisco GarcíA GonZÁLEZ (coord.), Vejez, envejecimiento y sociedad en España, siglos XVI-XXI, Cuenca, Universidad de CastillaLa Mancha, 2005, y Manuel González Portilla y Karmele Zarraga Sangroniz (eds.), Actas del IV Congreso de la Asociación de Demografía Histórica, Bilbao, Universidad del País Vasco, 1995.

70 AMB. Histórica. HI-5269, ff. 18-20. Aparecen informes de varios médicos de la ciudad que constatan sus patologías y denuncian los padecimientos que se seguirían del cambio de domicilio. 
citada Casa, desalojando de ella a la persona que oy la ocupa». El reto excedía lo puramente urbanístico — la «seguridad y permanencia de ella y uniformidad perfecta deel aspecto público» ${ }^{71}$ _. Estaban en juego la autoridad del conjunto de hombres célibes que conformaban el Cabildo catedralicio, su cuota de autonomía frente a las autoridades laicas y liberar «al Cavildo del desaire en que se hallaba» ${ }^{72}$.

El proceso contó con la habitual «Informazión de testigos». Éstos respondieron a un interrogatorio en el que se les preguntaba, en primera instancia,

[...] si es cierto, público y notorio que la casa que dhos Señores tienen en la plazuela llamada Sarmental, que está entre la Muralla y casas nuebas que rehedificaron el año passado de mil Setezientos sesenta y tres, $y$ al presente la havita $\mathrm{d}^{\mathrm{a}}$ Josefa Carrera, causa y hace notable deformidad al público, tanto mirada desde la misma Plazuela como desde el frente que da al Río y Puente, razón de ser mucho más vaja, desigual y de inferior Material y construcción en todas sus partes que las contiguas ${ }^{73}$.

\section{En segundo término, se cuestionó}

[...] si es cierto que esto se hace tanto más feo y reparable por estar, como está, pegando dha Casa con las otras nuebas y en un Sitio tan público como lo es la entrada principal en la Ciudad y en una plazuela donde exhisten los Edificios más destinguidos quales son la Cathedral, Palacio Arzobispal, Casa y Torre Consistorial, por lo que en el mismo año de Sesenta y tres determinaron dhos Sres rehedificarla, para quitar la expresada deformidad y mala vista, que no tuvo efecto por haverse opuesto a ello dn Pedro Thomé que la vivía con el pretexto de estar a su Cargo entonces la Administrazión del Excusado ${ }^{74}$.

71 ACCB. AC. LR 114. Cabildo del 13 de febrero de 1777, f. 201.

72 Ibidem, Cabildo del 13 de marzo de 1777, f. 212.

73 AMB. Histórica. HI-5269 (1777). La información de los testigos posibilitaba la presentación de las imprescindibles «Dilixencias» ante las autoridades municipales.

74 AHPB. PN. Alonso de Melo Peña. Legado 7.212 (15 de febrero de 1777), ff. 77-84. En tercer lugar se preguntó «si esta obra es tanto más necesaria en el día por haverse reconocido la Abenida que hubo por el Mes de junio del año pasado de mil setecientos y zinco, que con ocasión de pasar la Esgueba principal por debajo de la Casa, teniendo su desagüe por el Arco de la Muralla que hai en ella, se experimentó que por la estrechez de este, y no estar expedita como corresponde la Caja o Suelo de la misma Esgueba, retrocedieron las Aguas a una altura inesperada y desmedida y se inundaron todas las casas y plazuela, causando grave perjuicio y consternación pública, que fue bien notoria». En última instancia, «si es cierto que son muchas, quáles y quántas las casas que hai desocupadas en esta Ciudad, de capacidad, extensión y comodidad suficiente y correspondiente para qualquiera que tenga Empleo, Cargo o destino, a que no esté anexa la obligación de asistencia diaria a la Catedral». 
En resumen, y por todo ello, era indispensable ejecutar con toda brevedad la obra proyectada. Las respuestas de los testigos convocados por el Cabildo avalaban con sus deposiciones el punto de vista de la institución eclesiástica. De este tenor fueron las palabras del alcalde mayor perpetuo del Ayuntamiento, don Gaspar Vicente de la Concha, del regidor perpetuo, don Ramón Quintano, del notario mayor de la Audiencia Eclesiástica, don Francisco Luzuriaga, y del notario de la Audiencia arzobispal, don Felipe Anejo. Descuella especialmente la respuesta a la cuestión cuarta en la que los testigos hicieron una relación detallada y minuciosa de las circunstancias en que se hallaban múltiples inmuebles de la ciudad ${ }^{75}$.

Doña Josefa fue mucho más allá y en la defensa de sus intereses presentó la friolera de diez testigos que se decantaron abiertamente hacia sus tesis. El interrogatorio era explícito, conciso y cortante. ¿En qué estado se halla la casa? ¿Manifiesta alguna ruina? ¿Se vendieron recientemente dos casas acabadas de reedificar en la calle de la Calera? ¿Existe deformidad en el emplazamiento de la casa del Sarmental con respecto a las contiguas? ¿El deán vive en casa cómoda y en una de las más principales y suntuosas de la ciudad? ¿Se halla la inquilina administrando por cuenta de su majestad las dos gracias de la Santa Cruzada y la del papel sellado del Partido de Burgos y el Real Adelantamiento de Castilla, actividades en las que cobra y custodia los crecidos caudales de dichos ramos?

Todos los testigos aportados por doña Josefa, es decir, dos militares ${ }^{76}$, tres beneficiados parroquiales ${ }^{77}$, tres autoridades municipales ${ }^{78}$ y dos burócratas ${ }^{79}$, estaban, al unísono, de acuerdo en aseverar que la casa del Sarmental «no manifiesta que haga ninguna ruina alguna pues denota estar en buen estado por todos sus Costados», «no contempla Cause deformidad alguna, mucho menos quando la de la Esquina hace por un Costado a la Calle Real y todas Cinco por

75 AHPB. PN. Legajo 7.212 (15 de febrero de 1777), f. 80. «[...] en esta Ciudad hay al presente desocupadas muchas casas de bastante Capacidad, extensión y Comodidad Suficiente y de seguridad para qualesquiera que tenga empleo $[\ldots] »$.

76 AMB. Histórica. HI-5269 (1777). Don Felipe Díaz Ortega, regidor perpetuo y teniente coronel del Regimiento de Milicias de Burgos, y don José Muñoz, caballero del hábito de Santiago y ayudante mayor del citado Regimiento de Milicias.

77 Ibidem. Don José Fernández de Cadiñanos y don José Serrano, beneficiados en Viejarrúa, y don Isidro Díez, beneficiado en San Martín.

78 Ibidem. Don Francisco de la Infanta, regidor perpetuo y «hacendado», y don Vicente Gutiérrez y don Domingo Hontoria, diputados del Común de la ciudad. Nos hallamos ante individuos de notable talante «progresista» e ilustrado, con fieles adalides de las estrategias de gobierno de la Administración borbónica.

79 Ibidem. Don Vicente García Mendoza, abogado de los Reales Consejos y contador de los Propios y Rentas de la Ciudad, y don Pedro Antonio de Balmaseda, oficial de la Contaduría principal de Propios de la Provincia. 
la Plazuela forman Fachada, como es notorio uno y otro, y haver visto reedificar el tgo las tres Casas nuebas», que las «que se levantaron de nuevo años hace se hallan con igual disposición y altura [que] las dos de los extremos», que al lado de las casas recientemente erigidas en la Calera, las cuales casas vendió el Cabildo «inmediatamente», habitan miembros prominentes del Cabildo ${ }^{80}$, «que el Deán bive en Casa cómoda y una de las principales de esta Ciudad [...] cuia Casa es sumptuosa con las disposiciones que según el Carácter y Circunstancias del referido Deán puede necesitar y sin distancia para la pronta Concurrencia a su Sta Iglesia, en medio de mantener como mantiene Coche» y que doña Josefa «cobra, percibe y custodia los Caudales quedan de si estos ramos y que de la misma Casa sale la Comitiva para la publicazión de la Bula y a cuia Casa concurre todo el Vecindario por las Bulas que necesita y el papel sellado y los Lugares del Arzobispado a hacer sus respectibas pagas». Los testigos presentados por doña Josefa negaron las acusaciones de deterioro y fealdad que había esgrimido el Cabildo, ridiculizaron literalmente al deán y adujeron como un aspecto esencial para el mantenimiento de la vivienda objeto de litigio que la casa de doña Josefa era un referente fundamental «del acompañamiento de ministros, [casa] a la que concurren todos los Vecinos y Moradores a tomar las Bulas que necesitan para si y sus Familias, y los Pueblos a pagar, las quales se les entregan en las Veredas, que se despachan, recibiendo y resguardando en la misma Casa dha $\mathrm{d}^{\mathrm{a}}$ Josefa los caudales de uno y otro ramo». Desalojar dicha casa provocaría un auténtico caos y quebraría un servicio público que venía siendo habitual para mucha gente desde hacía más de treinta años.

El Concejo, puesto entre la espada y la pared, se vio obligado a intervenir. Se nombraron, a petición de doña Josefa, dos peritos «para el reconocimiento de la casa en que abita». La cuestión que se les planteaba a Luis Céspedes y Juan Díez de Güemes ${ }^{81}$ era peliaguda, dado que habrían de emitir un informe forense sobre «si amenaza o no ruina» la casa en disputa. Su declaración no tiene desperdicio:

La expresada Casa no sólo no amenaza ruina interior ni exteriormente, pues la han reconocido menudamente y con el mayor Cuidado, sino que se halla con toda Seguridad y su Fábrica es nueba y hecha por los años de mil Setecientos veinte y Cinco o veinte y seis, pues la vio ejecutar el expresado Juan Díez de Güemes según

80 AMB. Histórica. HI-5269 (1777). En casas de La Calera residían el magistral y dos canónigos, individuos que «no tienen Coche y están a mucha mayor distancia».

${ }^{81}$ Tanto uno como otro eran maestros de obras. El primero era titular del Ayuntamiento y uno de sus alarifes. El segundo ejercía sus quehaceres profesionales en el Hospital del Rey. Las citas textuales de estos párrafos proceden de AMB. Histórica. HI-5269 (1777). 
hace memoria sin embargo de que en aquel tiempo tendría sólo como de a ocho a nueve años.

La manifiesta desproporción en el número de testigos presentados por una y otra parte y el incuestionable disenso de sus discursos no acalló, no obstante, el litigio y las autoridades capitulares, en vez de desistir, incrementaron la presión y el asfixiante acorralamiento sobre doña Josefa.

El 13 de marzo de 1777 se dio la orden urgente, no obstante, de forzar el desalojo y se comenzaron los trámites para ejecutar una reedificación largamente deseada. Se tomaron medidas del terreno, que fueron remitidas a Madrid para que «se formase allí por Maestro de mucha práctica e inteligencia el Plan o Planes conducentes [...] a executar la obra ${ }^{82}$. En el Cabildo del 21 de mayo, el deán anunció que don Juan Durán, maestro mayor de la Villa y Corte de Madrid, se había ocupado de trazar los planos, circunstancia que «juntamente con el abanze de costo que tendrá la citada obra, hecha por Santiago Pérez» ${ }^{83}$.

Doña Josefa inició una ofensiva mediática y judicial con objeto de evitar ser finalmente desahuciada. En junio de 1777 esgrimía en su defensa hallarse «con la edad de 86 años, [estar] impedida y molestada de varios accidentes» y haber llegado a su noticia extrajudicialmente «que por el mismo cavildo o algunos de sus Individuos reintentan precisarme a desocuparla, lo que precisamente ha de ser mui perxudicial y exponerme a perder la vida» ${ }^{84}$.

Ante el cariz de los acontecimientos, doña Josefa, una mujer de lanas tomar, movió, en agosto, los hilos judiciales y rubricó otro «Poder» que activara las estrategias de defensa ante «la Causa que me han movido los Sres Deán y Cavildo de la Sta Iglesia Metropolitana sobre que deje libre y desembarazada la Casa que habito pretestando necesidad de obra en ella o reedificarla de nuevo». Le parecía un despropósito inadmisible que le obligaran a abandonar una vivienda que ocupaba desde «hace más de Cinquenta y dos años, cuya renta he satisfecho puntualmente y que de tener efecto sin duda se me seguirá notable daño en la salud y aún exponerme a perder la vida por mi abanzada hedad de 86 años y aczidentes avituales». En una machacona, obsesiva y reiterada letanía repetía su negación a abandonar la casa por la «abanzada hedad y peligro de la vida de precisarme mudar de Casa y que esta no padece ruina» ${ }^{85}$.

82 ACCB. AC. LR 114. Cabildo del 13 de marzo de 1777, f. 212.

83 Ibidem, Cabildo del 21 de mayo de 1777, f. 249. Con un desembolso aproximado de 60.000 reales de vellón, la obra sacaría del limbo constructivo la proyectada supresión de la conflictiva escuadra de la plazuela del Sarmental.

84 AHPB. PN. Francisco de Villafranca. Legajo 7.100 (18 de junio de 1777), f. 77.

85 Ibidem (15 de septiembre de 1777), ff. 165-166. Buena prueba de su determinación de defender con unas y dientes el usufructo del alquiler del Sarmental, y de su talante como mujer y «empresaria», era 
La irritación de los capitulares creció vertiginosamente como consecuencia de «la resistencia de la misma $\mathrm{D}^{\mathrm{a}}$ Josefa Carrera, no obstante las órdenes que se le han comunicado para que la desembarazase para el día de San Juan» ${ }^{86}$. Era el 27 de julio y la viuda no cedía. En forma alguna quería abandonar la casa del Sarmental. Se decidió entablar acciones judiciales en Madrid y en Valladolid ${ }^{87}$. Los capitulares catedralicios se sentían, además de frustrados, ridiculizados. En un curioso documento de noviembre de 1777, indicaban que a doña Josefa Carrera numerosos testigos

[...] la han visto en los más o quasi todos los días salir a pasear por tarde y mañana con mucha robustez y firmeza $[\ldots]$ haviendo observado al mismo tiempo que no ha hecho demostración ni mobimiento alguno para mudarse de la Casa en que havita en la Plazuela del Sarmental, propia de los dhos Señores [...] sin embargo de hallarse requerida con ejecutoría de S. M. y Señores Presidente y Oydores de la Real Chancillería de Valladolid por la que se le manda que en el preciso y peremptorio término de un mes [la] deje desembarazada.

La animadversión del Cabildo le hacía caer en el desprecio por quien osaba menoscabar su autoridad y utilizar los más bajos argumentos para destruir su credibilidad. Las andanzas de doña Josefa — señalaban los responsables del Cabildo - han causado «y causan notable admiración a los testigos y demás de este Pueblo, viendo el poco aprecio que la expresada hace de unos mandatos $\tan$ supremos y respetables para ser obedecidos $»^{88}$. Los testigos ${ }^{89}$ puntualizaban que «ha salido en los más días al presente mes a pasearse, por las tardes regularmente desde las dos hasta las quatro o las Cinco, y en muchos días ha salido también por la mañana [...] [aunque] no ha visto que hasta aora se haya salido de ella [de la casa] ni menos dado prinzipio a la mudanza de trastos» ${ }^{90}$.

que llegó a solicitar, en su defensa jurídica, «imponer Silencio a el referido Cavildo y hasta que lo consiga y todo lo demás que ceder a mi derecho».

86 ACCB. AC. LR 114. Cabildo del 27 de julio de 1777, f. 278.

${ }^{87}$ El 17 de octubre el Cabildo fue informado de la existencia de un auto de la Chancillería a su favor, auto emitido el 13 de octubre. Ibidem, Cabildo del 17 de octubre de 1777, f. 377. En el auto se ordenaba que doña Josefa dejara libre y desembarazada la casa en el plazo de un mes para que el Cabildo pudiera llevar a cabo las obras que tenía proyectadas.

${ }^{88}$ AHPB. PN. Alonso de Melo Peña. Legajo 7.212 (27 de noviembre de 1777), ff. 481-484.

${ }^{89}$ Los testigos aportados por el Cabildo fueron, en esta ocasión, dos clérigos de escaso rango, dos maestros libreros y un paje-estudiante, residente en casa de un canónigo.

90 AHPB. PN. Alonso de Melo Peña. Legajo 7.212 (27 de noviembre de 1777), ff. 481-484. Era según los testigos_ «Arrojo y temeridad el no cumplir y ejecutar lo que un tribunal tan superior manda; y por ser una Cosa tan mal vista y parecida la referida inobediencia, se persuade a que nadie que no fuese un temerario haría semejante desprecio, mayormente quando el Cavildo tiene hecho ya en la Plazuela un grande acopio de Materiales para principiar la Obra». 
En apoyo de su madre apareció en escena el arcediano de Burgos, don Pedro Celestino Tomé ${ }^{91}$. El 5 de diciembre de 1777 ante el Cabildo hizo un panegírico de los servicios de la familia a la catedral ${ }^{92}$ y de la situación de su progenitora $^{93}$.

El arcediano se encontraba en una difícil disyuntiva ${ }^{94}$. Por un lado, estaba inclinado hacia «el amor natural de hijo al devido cuidado del sosiego, salud y vida de su afligida Madre» y, por otro, estaba vinculado al «respeto y la autoridad» por el Cabildo del que formaba parte como una de sus principales dignidades. Deseoso de paz y armonía, esgrimía sus propios méritos, «los de su Padre y su tío en tantos años de serbicio en la Iglesia», y la necesidad de ser «generoso, magnánimo y noble» con «la ancianidad y deplorable situación de su Madre $»^{95}$ como argumentos decisivos. La propuesta del arcediano era que se mantuviera de por vida a su «enferma, decrépita, octogenaria y sentida» madre en la casa del Sarmental con el aumento del alquiler desde los 645 a los 1.500 reales, incremento que él devengaría de su propia prebenda capitular ${ }^{96}$.

${ }_{91}$ ACCB. AC. LR 114. Cabildo del 5 de diciembre de 1777, ff. 403-404. Sobre sus andanzas y problemáticas personales, Francisco SANZ DE LA Higuera, «Carrera eclesiástica y algunos deslices de Felipe del Hoyo Santamaría y Pedro Celestino Tomé, arcedianos de Burgos (1731-1784)», Hispania Sacra, 124 (2009), págs. 649-690.

92 Su padre, don Pedro Tomé, había sido mayordomo del Cabildo durante varios años (1720-1733). Su tío, don Felipe Carrera, hermano de doña Josefa, fue durante más de treinta años canónigo y él mismo ocupó desde 1751 a 1784 un puesto destacado en el Cabildo como arcediano de Burgos, responsable del coro de su nombre y segundo en el esquema de poder de la catedral después del deán.

93 El arcediano aducía que hacía «cinquenta y tres años que su Madre D ${ }^{\text {a }}$ Josefa Carrera habita en la Plazuela del Sarmental una Casa perteneciente a V. J., y hallándose esta Señora continuamente enferma, impedida y espuesta a una sofocación por el accidente de pecho que padece y con la edad de 85 años, la ocurre ahora la sensible novedad de que V. J. intenta expelerla de su antiguo habitación, en cuio sólo hecho ha formado la más viva aprehensión de que ha de perder la vida, sin que las continuas y eficaces persuasiones del Arcediano para que deponga tan funesto concepto alcancen a desvanecerse, ante bien la sirban en su pesadumbre de mayor tormento y dolor y sus lamentos y lágrimas le penetran el Corazón». ACCB. AC. LR 114. Cabildo del 5 de diciembre de 1777, ff. 403-404. Don Pedro Celestino era una persona de carácter difícil y de andanzas irregulares, idiosincrasia que le generó hoscas disputas con sus padres y hermanos y con múltiples «compadres» capitulares. Las graves acusaciones por él vertidas levantaron ampollas en la paciencia de algunos de los prebendados catedralicios y generaron una indignación y una rabia difícilmente contenida. Véase Gregorio Bartolomé Martínez, Los clérigos a la greña, Alicante, Club Universitario, 2010, en especial las págs. 177-196.

94 Por decirlo con sus propias palabras, se hallaba «en la mayor perplejidad y tribulación».

95 Ibidem, ff. 403-404. Pedro Celestino no se mordía la lengua al aseverar que «mediante los avituales y graves accidentes que padece es cortísimo el plazo de su vida». De su óbito en tales circunstancias era culpable, sin duda, el Cabildo o, entre sus componentes, aquellos que apostaban sin escrúpulos por el desahucio de la vivienda ocupada por la viuda.

96 «...] en prueba de que cuida de los más promptos y seguros intereses de V. S. y del filial cariño que naturalmente profesa a dicha Señora». ACCB. AC. LR 114. Cabildo del 5 de diciembre de 1777, f. 404. Don Pedro Celestino era responsable, no obstante, de haber irritado a su madre hasta la extenuación. En un «Cobdicillo» que se redacta en 1774, doña Josefa advierte a su hijo clérigo que únicamente recibiría los ajuares que le destinaba en sus últimas voluntades si se dejaba guiar por la «Vondad y [la] humildad [...] y guardará 
La respuesta a las propuestas de don Pedro Celestino llegó, con vehemencia y no disimulada animadversión, del doctoral Ramírez. El 8 de diciembre de 1777 señaló que la pretensión del Tomé era «la más indecorosa e intempestiva que se puede proponer», adjetivos al que sumaba otro no menos aciago, «despreciable» ${ }^{97}$. Es evidente, como se ha comprobado en otras ocasiones, que en el seno del Cabildo catedralicio existían poderosas y notorias desavenencias y enemistades entre los prebendados, algunas de las cuales llegaban a la más profunda de las inquinas. El Cabildo estaba sometido desde 1763 a un rosario de irreverencias por parte de una familia y, en especial de una inquilina, «quien blasonó y ha blasonado infinito, como también el Señor Arcediano y todos sus adherentes, de tener deprimida la Autoridad y potestad del Cavildo», institución que había sido reiteradamente insultada «por varios medios y modos». Frente a las exquisitas diligencias del deán y del Cabildo, doña Josefa Carrera y su hijo «se jactaron sobre manera con todos sus aliados de que no era V S capaz de poder conseguir esta empresa [la reedificación de la casa y la supresión de la deformidad del aspecto público] [...] con expresiones a la Verdad muy agenas del decoro» ${ }^{98}$.

Doña Josefa, como hizo en su momento Pedro Tomé, no tuvo escrúpulos en involucrar a las autoridades madrileñas. Don Manuel Ventura de Figueroa, fiscal general de la Santa Cruzada, se posicionó abiertamente en defensa de los intereses de la inquilina, que no eran otros que los del rey y de la administración borbónica. Se exigió al Cabildo que la casa «quedase destinada a nre del Real Servicio para la seguridad del Sumario de la Bula y sus caudales», al presidente de la Real Chancillería de Valladolid que no expidiese el auto del 30 de enero y al alcalde mayor que, en caso de llegar las órdenes de ejecución de la Chancillería, las archivara. El Cabildo, en un renovado amilanarse ante el ímpetu

con su Hermano Dn Antonio, como se lo pido con el Amor y Cariño que le tengo, la buena Armonía, paz y quietud que es debida entre Hermanos y no dará lugar a Pleitos ni diferencias, que en ellos se Consuma el Caudal que tantos desbelos me a Costado y a su Padre el ganarle». AHPB. PN. Alonso de Melo Peña. Legajo 7.210 (21 de marzo de 1774), ff. 120-121.

97 Ibidem, Cabildo del 8 de diciembre de 1777, ff. 408-411. Es de suponer el hastío y la repugnancia que causaba en la inmensa mayoría de los componentes del Cabildo la presencia de un individuo bronco, fornicador, pendenciero y contrario a los intereses primigenios de la institución catedralicia. El Cabildo de Burgos tenía experiencia sobrada en esos terrenos. Véase Francisco SANZ DE LA Higuera, «¿Qué había debajo del "solideo con orejeras" del canónigo Verde Sañudo? (Burgos, 1707-1718)», Historia y Genealogía (en proceso de evaluación).

98 Los 700 reales de aumento en el alquiler que proponía el arcediano le parecían a Ramírez un nauseabundo plato de lentejas que atentaba contra el «honor, toda su autoridad, el celo del bien y aspecto público, el cuidado de procurar habitación a sus Individuos y el precaver los perjuicios» que eran inherentes al Cabildo. ACCB. AC. LR 114. Cabildo del 8 de diciembre de 1777, ff. 408-411. Aguas turbulentas y peligrosas agitaban las conversaciones dentro y fuera de la sala capitular de la catedral y las perspectivas de futuro no se decantaban por la concordia, sino más bien por todo lo contrario. 
de las exigencias de los políticos cortesanos, decidió plegarse a la solicitud de Figueroa y, «sólo en obsequio suyo y darle una clara muestra de su mayor rendimiento», sobreseía, de momento, el asunto a pesar «del claro derecho que le asiste [...] y no obstante la instancia Fiscal excitada últimamente» ${ }^{99}$.

El 17 de marzo de 1778 el deán repartió las habas. Aparecieron seis negras y quince blancas $(71,4 \%)$, «con que a pluralidad de votos» quedó aprobado presentar una «Representación al Señor Gobernador» ${ }^{100}$. En ese documento, el Cabildo hacía un relato pormenorizado del affaire y exigían fueran respetados sus derechos como propietario del edificio ${ }^{101}$. En mayo aún seguían empantanados, si bien la solución al problema estaba cercana. De orden de don Antonio de la Cuadra, secretario de la Comisaría General de la Santa Cruzada, y, en última instancia por elevación, del comisario general de la misma, se determinaba que la «Viuda Tesorera» ${ }^{102}$ fuera mantenida en la casa que habita «y en que han estado y se hallan depositados con seguridad los Sumarios de la Sta Bula y peltrechos para su publicación y caudales de sus limosnas por aora y mientras que siguiese sirviendo el oficio de Thesorera de Cruzada del Arzobispado [...] pagando la inquilina los alquileres» ${ }^{103}$.

El ajuste del arrendamiento se efectuó, con la regulación mediadora de dos peritos, uno nombrado por cada parte, en el Cabildo del 22 de mayo de 1778. Doña Josefa abonaría anualmente 1.100 reales de vellón por el alquiler de la casa $^{104}$. Los perjuicios ocasionados como consecuencia del acopio de materia-

99 ACCB. AC. LR 114. Cabildo del 16 de enero de 1778, ff. 496-497. El Cabildo exigía que se le indemnizara por los daños y perjuicios que la tenacidad de la tesorera de la Santa Cruzada le habían ocasionado, incluyendo las pérdidas de materiales para la obra de la casa, y que la inquilina abonara el montante del alquiler que ella misma había estimado ofrecer voluntariamente. La «notoria justificación de los Ministros del Rey» allanaba todos los caminos y deshacía todos los entuertos.

$100 \quad$ Ibidem, Cabildo del 17 de marzo de 1778, f. 500.

101 Descuella, en especial, la siguiente consideración: «Era reparable quisiese abusar de su empleo para no dejar a su Propietario la Casa que habita, quando le dan de tiempo hasta San Juan para mudarse a otra». Ibidem, Cabildo del 23 de marzo de 1778, f. 503.

102 Ibidem, Cabildo del 18 de mayo de 1778, f. 544. Es muy significativo, a mi modesto entender, que el comisario general de la Santa Cruzada se refiriera a la «Viuda Tesorera» enfatizando las mayúsculas, que ningunease los intereses del Cabildo y protegiera los intereses del Estado.

103 ACCB. AC. LR 114. Cabildo del 18 de mayo de 1778, f. 544.

104 ACCB. AC. LR 114. Cabildo del 22 de mayo de 1778, f. 549. El alquiler pasaba de 645 a 1.100 reales/año. Doña Josefa se lo podía permitir. En el inventario post mórtem elaborado a la hora de su fallecimiento se computó un patrimonio superior a los 880.000 reales. AMB. Histórica. HI-5253 (26 de febrero de 1782), ff. 1-71. Sobre este apasionante aspecto véanse, en otras muchas posibilidades, Yves Aubry, «Pour une étude du veuvage fémenin à l'époque moderne», Histoire, Économie et Société, 2 (1989), págs. 223-236. Vivien BRODSKY, «Viudas en Londres a finales del reinado de Isabel I: nuevas nupcias, oportunidades económicas y orientaciones familiares», en Lloyd Bonfield, Richard Sмiтh y Keith Weighton (comps.), El mundo que hemos ganado. Estudios sobre población y estructura social. Homenaje a Peter Laslett en su 70. ${ }^{\circ}$ aniversario, Madrid, Ministerio de Trabajo y Seguridad Social, 1990, págs. 157-195. María Ángeles Ortego Agustín, «El ámbito doméstico de las mujeres viudas en la sociedad madrileña del siglo XviII», Nuevo Mundo, Mundos Nuevos, co- 
les para la obra quedarían cicatrizados con el desembolso de 900 reales. Las costas del proceso judicial quedaron en manos del Cabildo, quien, además del tremendo sentimiento de derrota y humillación generado por una mujer, viuda y anciana, hubo de desprenderse de 2.160 reales y 30 maravedíes $^{105}$. Lo más grave, sin duda, era que después de catorce años de conflicto entre el Cabildo y Tomé, primero, y su viuda, después, la reedificación no se había podido llevar a efecto y mientras no se extinguiese la vida de doña Josefa nada más se podría objetar. El Cabildo catedralicio había sido vapuleado por una pareja de ancianos que contaban con el apoyo y beneplácito de las autoridades borbónicas y con un poderoso patrimonio que los colocaba en la cúspide social y económica de la ciudad ${ }^{106}$.

\section{El objeto del deseo y la desazón: la casa de la plazuela del Sarmental}

Las excelentes descripciones que del interior de las viviendas de Pedro Tomé y Josefa Carrera se entresacan en sus respectivos inventarios post mórtem ${ }^{107}$ nos permiten adentrarnos en la calidad de sus estancias y en la disposición del atrezo doméstico ${ }^{108}$. En ambos documentos se aprecia un lujo de detalles, una búsqueda de confort y de calidad de vida y una adecuación del mobiliario a las precisas funciones que se le atribuían ${ }^{109}$, propias de un hogar

loquios (2008), [en línea] <http://nuevomundo.revues.org/index20242.html>. Robert McCAA, « ¿Por qué había tantas viudas en el México borbónico?», en Pilar Gozalbo (ed.), Las familias nobohispanas, siglos XVI-XIX, México, El Colegio de México, 1991, págs. 299-324, y Serrana Rial García, «Las mujeres "solas" en la sociedad semi-urbana gallega del siglo XvıII», Obradoiro de Historia Moderna, 8 (1999), págs. 169-197.

105 ACCB. AC. LR 114. Cabildo del 17 de mayo de 1780, ff. 522-525. En dicha sesión se efectuó un seguimiento pormenorizado del acontecer del pleito con doña Josefa. Las costas que el Cabildo satisfizo fueron las siguientes: 18 reales al procurador de la ciudad, 1.098 reales al procurador de Valladolid, 909 reales al escribano Melo Peña y 136 reales al agente de Madrid.

106 El inventario post mórtem de Pedro Tomé sumaba una cifra realmente substancial para el Burgos de mediados del Setecientos, 1.509.477 reales. Era, sin duda, uno de los más voluminosos patrimonios de la ciudad. AHPB. JM. José Antonio Fernández Guilarte. Legajo 977 (14 de julio de 1764), ff. 21-127. El Cabildo no contemplaba los 455 reales que de aumento percibiría anualmente como una victoria pírrica. Era, sencillamente, un irrisorio incremento con el que no podía enmendar ni el hazmerreír privado ni el descrédito público a que les había conducido su terquedad y su estrategia de enfrentamiento con las «covachuelas» del Estado y con el «Midas» de la economía burgalesa.

107 AHPB. JM. Antonio Fernández Guilarte. Legajo 977 (14 de julio de 1764), ff. 21-127, y AMB. Histórica. HI-5253 (26 de febrero de 1782), ff. 1-71.

${ }_{108}$ Los planos que acompañan a este trabajo no son más que una reconstrucción aproximada de la distribución horizontal y vertical del hogar de los Tomé, composición sujeta a la interpretación de las estancias significadas por el escribano en el inventario post mórtem.

109 La existencia de una notable especialización en el uso de las estancias se aprecia en la disposición del mobiliario y de los elementos decorativos. Lejos de la mezcolanza y la escasez de los menos afortunados, en el hogar de los Tomé se disfrutaba de comodidad y confort. Cada planta del edificio permitía el desarrollo 


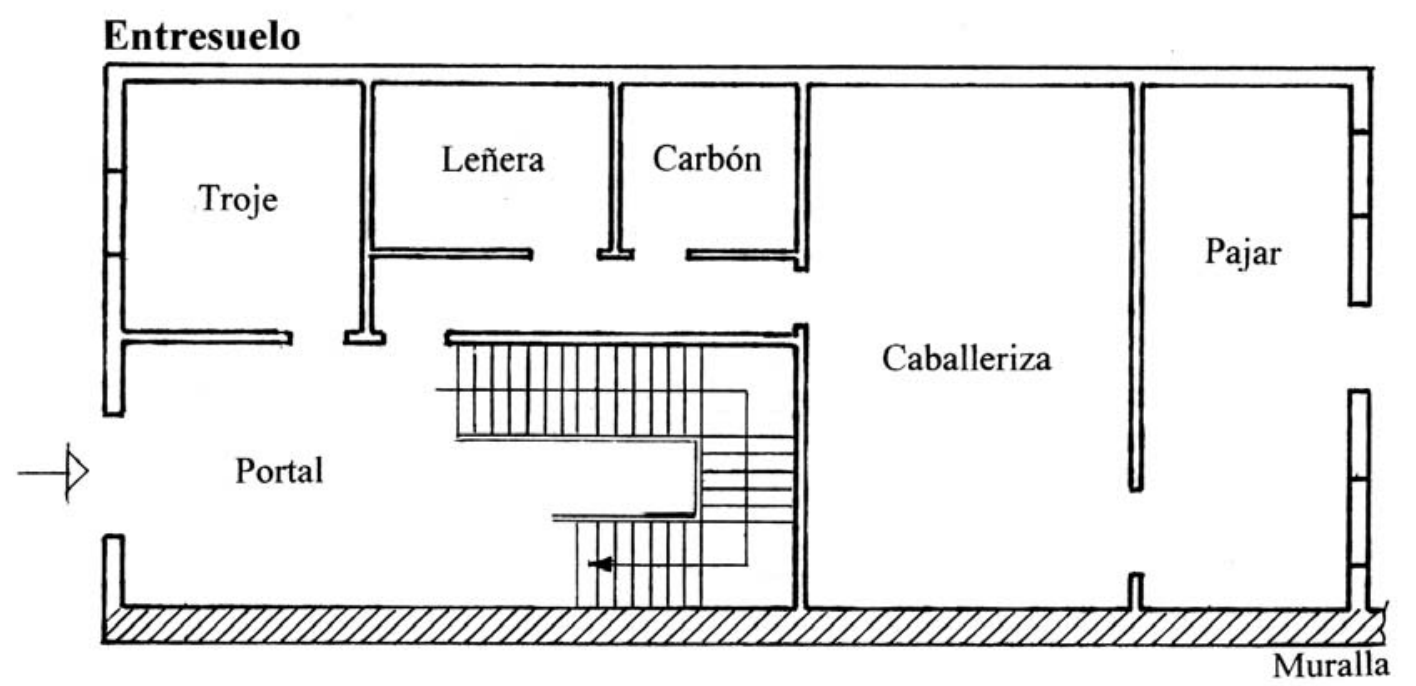

\section{Primera Planta}

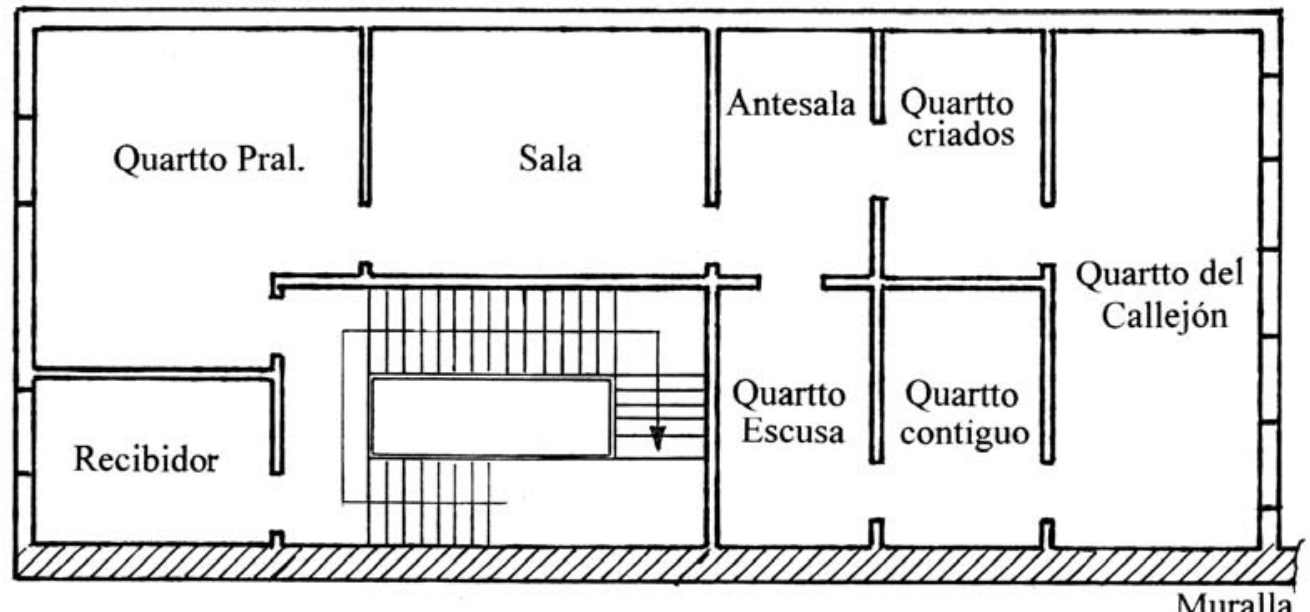

\section{Segunda Planta}

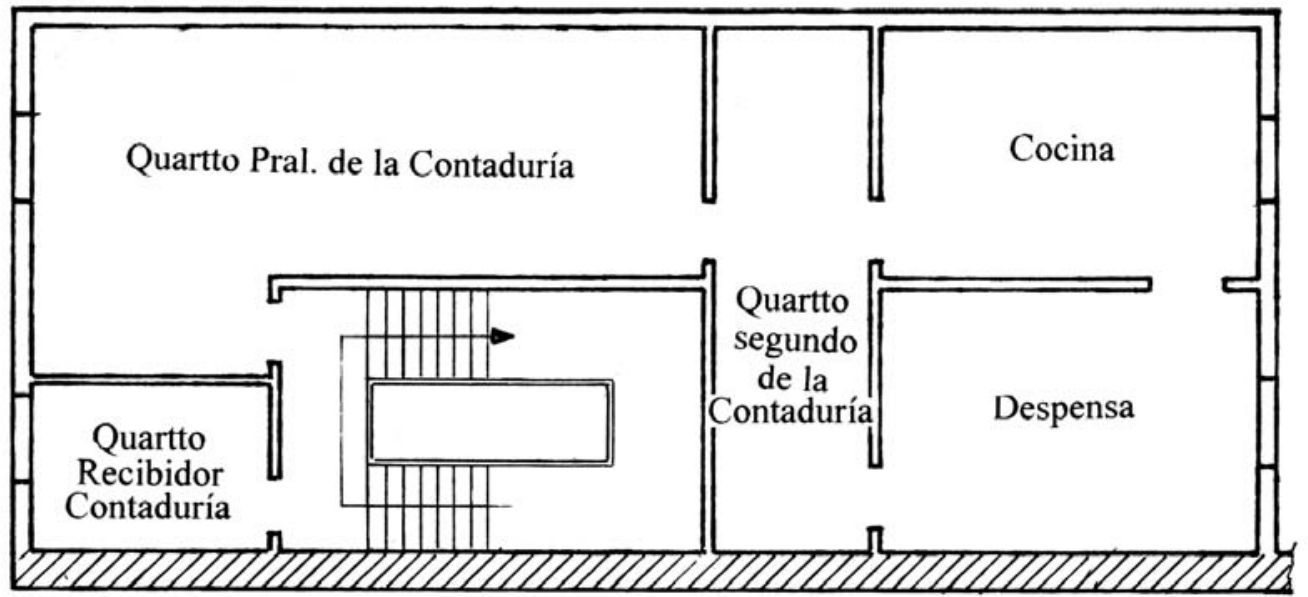

Muralla

Planos. Reconstrucción aproximada de las estancias de la casa del Sarmental, vivienda de don Pedro Tomé y doña Josefa Carrera. Nicolás Pérez Rosado (C 2008. 
privilegiado, similar a lo dispuesto en las mansiones más aristocráticas. Las diecisiete piezas diferenciadas de la casa del Sarmental respondían al modelo de casa-oficina de los burócratas de mayor alcurnia y nivel de fortuna ${ }^{110}$.

En el IPM elaborado en el momento del óbito de don Pedro Tomé (1764), la vivienda primera disponía de una «Cozina», una «Espensa» (almacén), un «Quarto $1^{\circ}$ Principal» (dormitorio), un «Quarto $2^{\circ}$ » (sala de estar y oratorio), un « $3^{\circ}$ Quarto de escusa» (dormitorio), un « $4^{\circ}$ Quarto contiguo a el de escusa» (dormitorio y ropero), un «Quarto de las criadas» (dormitorio) y un «Rezividor». La «Vibienda 2a $2^{\mathrm{a}}$ contaba con un «Quarto de rezividor», un «Quarto prinzipal de Contaduría» (despacho), un «Quarto $2^{\circ}$ de la Contaduría» (gabinete), una antesala, una « $2^{\text {a }}$ Sala» y un «desbán». En el entresuelo se señala la existencia de una «Quadra deel Portal» y de un «Callexón» y se adivinan, aunque no estén explícitamente enunciados, unas trojes (granero), unas caballerizas y una «cochera» ${ }^{111}$, carboneras y leñera y un pajar.

Las estancias pormenorizadas en 1782, año de la muerte de doña Josefa, eran, también, múltiples y ofrecían la distribución habitual de una casa de grandes dimensiones, propia de gente adinerada y de vivir confortable ${ }^{112}$.

Pedro Tomé y Josefa Carrera estaban instalados en la vivienda del Sarmental desde hacía muchos años como para que se les obligara a mutar su cotidianidad con un traslado traumático. Aunque no eran propietarios de los inmuebles donde se alojaban, se sentían muy a gusto en el que consideraban su único y legítimo hogar. El desalojo era inconcebible. Los compradores de

de unas funciones contrastadas. En la planta principal, la intimidad familiar. En la segunda vivienda, los quehaceres profesionales. En el entresuelo, la logística doméstica y la apertura a la calle. Véanse, entre otras propuestas, los análisis de Gloria Franco Rubio, «La vivienda en el Antiguo Régimen: de espacio habitable a espacio social», Chronica Nova, 35 (2009), págs. 63-103, y «La vivienda en la España ilustrada: habitabilidad, domesticidad y sociabilidad», en Ofelia Rey Castelao y Roberto López (eds.), El mundo urbano en el siglo de la Ilustración, Santiago de Compostela, Xunta de Galicia, 2009, págs. 125-135.

110 Francisco SANZ DE LA Higuera, «Familia, hogar y vivienda...», págs. 199-202, y «"Estando como estamos juntos..."», págs. 388-393.

111 Francisco SANZ DE LA Higuera, «Una estancia doméstica que se mueve...», págs. 469-506.

112 Su distribución interna ofrecía un «Quarto Principal» (dormitorio), un «Oratorio», una «Despensa» (almacén), un «Recibidor», un «Quarto siguiente al del Estrado» (comedor), un «Callejón para la cocina saliendo del quarto oratorio», un «Quarto siguiente a dho Callexón» (dormitorio), un «Quarto del Peso» (almacén), un «Callexón para la cocina», un «Quarto de Bullas» (almacén), una «Cozina», un «Quarto de arriba antes del Despacho» (dormitorio), un «Despacho» (gabinete), un «Quarto siguiente al Despacho»y un «Desbán detrás del Despacho». En última instancia, se anotaron una «Despensa de Abajo» y un «Quarto del cochero», estancias sitas en el entresuelo, inmediatas a la caballeriza y la cochera, el portal, la carbonera, la leñera y las trojes y el pajar. La casa de la plaza del Sarmental no era una mansión nobiliaria en sentido estricto. Empero, estaba a años luz de las infraviviendas ocupadas por gran parte de la población burgalesa. El tamaño de los suelos, el número de habitaciones y sus condiciones de salubridad colocaban el hogar de los Tomé en una posición de privilegio que, como es lógico, no querían abandonar en modo alguno, aunque para ello tuvieran que enfrentarse con quien fuera necesario, incluso con el poderoso Cabildo catedralicio. 
bulas y de papel sellado, fueran de la ciudad o de otras muchas localidades del Arzobispado, tenían esa casa como referente esencial de sus desplazamientos y andanzas, circunstancia que era igualmente refrendada por los responsables de la Santa Cruzada. Las enormes sumas de dinero que se manejaban en dicha administración hacían preciso continuidad, seguridad y discreción, es decir, facilidades para los compradores y dificultades para los delincuentes. 